\title{
Nutrient demand interacts with legume particle length to affect digestion responses and rumen pool sizes in dairy cows
}

\author{
K. L. Kammes, Y. Ying, and M. S. Allen ${ }^{1}$ \\ Department of Animal Science, Michigan State University, East Lansing 48824-1225
}

\begin{abstract}
Effects of legume particle length on dry matter intake (DMI), milk production, ruminal fermentation and pool sizes, and digestion and passage kinetics, and the relationship of these effects with preliminary DMI (pDMI) were evaluated using 13 ruminally and duodenally cannulated Holstein cows in a crossover design with a 14-d preliminary period and two 19-d treatment periods. During the preliminary period, pDMI of individual cows ranged from 22.8 to $32.4 \mathrm{~kg} / \mathrm{d}$ ( mean $=26.5$ $\mathrm{kg} / \mathrm{d}$ ) and $3.5 \%$ fat-corrected milk yield ranged from 22.9 to $62.4 \mathrm{~kg} / \mathrm{d}$ (mean $=35.1 \mathrm{~kg} / \mathrm{d})$. Experimental treatments were diets containing alfalfa silage chopped to (1) $19 \mathrm{~mm}$ (long cut, LC) or (2) $10 \mathrm{~mm}$ (short cut, $\mathrm{SC}$ ) theoretical length of cut as the sole forage. Alfalfa silages contained approximately $43 \%$ neutral detergent fiber (NDF); diets contained approximately $47 \%$ forage and $20 \%$ forage NDF. Preliminary DMI, an index of nutrient demand, was determined during the last $4 \mathrm{~d}$ of the preliminary period, when cows were fed a common diet, and used as a covariate. Main effects of legume particle length and their interaction with pDMI were tested by ANOVA. Alfalfa particle length and its interaction with pDMI did not affect milk yield or rumen $\mathrm{pH}$. The LC diet decreased milk fat concentration more per kilogram of pDMI increase than the SC diet and increased yields of milk fat and fat-corrected milk less per kilogram of pDMI increase than the SC diet, resulting in a greater benefit for $\mathrm{LC}$ at low pDMI and for $\mathrm{SC}$ at high pDMI. The LC diet tended to decrease DMI compared with the SC diet. Ruminal digestion and passage rates of feed fractions did not differ between LC and SC and were not related to level of intake. The LC diet tended to decrease the rate of ruminal turnover for NDF but increased NDF rumen pools at a slower rate than the SC diet as pDMI increased. This indicated that the faster NDF turnover rate did not counterbalance the higher DMI for SC, resulting in larger NDF
\end{abstract}

Received September 6, 2011.

Accepted December 4, 2011.

${ }^{1}$ Corresponding author: allenm@msu.edu rumen pools for SC than LC. As pDMI increased, LC increased ruminal digestibility of potentially digestible NDF and total NDF, and SC decreased them, but total-tract digestibilities of potentially digestible NDF, total NDF, organic matter, and dry matter were lower for LC than for SC. Ruminal digestibilities of starch and organic matter interacted quadratically with level of intake. When legume silage was the only source of forage in the diet, increasing chop length from 10 to $19 \mathrm{~mm}$ tended to decrease DMI but did not negatively affect productivity of cows.

Key words: particle size, alfalfa silage, digestion kinetics, rumen pool

\section{INTRODUCTION}

Optimal utilization of diets by dairy cows is influenced by the chemical composition and physical characteristics of feeds. Forage fiber, in a form that is physically effective, is necessary in dairy cow diets to promote rumen fermentation and function (Allen, 1997). Increasing forage particle size has been shown to increase chewing activity, resulting in increased saliva flow, rumen $\mathrm{pH}$, acetate-to-propionate ratio, and milk fat concentration (Nørgaard, 1993; Beauchemin et al., 1997), increase ruminal retention time (Dixon and Milligan, 1985), and promote formation of the rumen mat (Grant, 1997). Although impaired rumen function and health can result when cattle are fed rations lacking in physical structure, excessive amounts of long, coarse fiber may decrease ruminal digesta passage rates and limit feed intake of lactating dairy cows when feed intake is limited by rumen fill (Allen, 2000).

Forage particle length (FPL) has been widely researched, but results of animal responses to FPL are inconsistent and inconclusive. These inconsistencies are likely due to large variation in dietary factors among studies, which make direct comparisons across studies difficult. Wide ranges of FPL (2 to $32 \mathrm{~mm}$; Tafaj et al., 2007) and differences between FPL compared within studies (6 vs. $8 \mathrm{~mm}$, Yang and Beauchemin, 2004; 24 vs. $170 \mathrm{~mm}$, Randby et al., 2008) have been used to evaluate FPL. Additionally, studies often evaluate the 
effect of FPL in combination with other dietary factors including forage:concentrate ratio (Soita et al., 2000; Einarson et al., 2004), grain processing (Yang et al., 2001), grain fermentability (Krause and Combs, 2003), nonforage fiber sources (Mooney and Allen, 1997), and supplemental fat (Onetti et al., 2003). Furthermore, responses to FPL vary depending on preservation methods (hay, silage) and forage source with greater differences reported for legume and grass-based TMR compared with corn silage-based TMR (Tafaj et al., 2007). This suggests that consideration of forage family is necessary when studying the effects of particle size. Alfalfa (AL; Medicago sativa) was selected as a representative legume for use in this experiment because it is the predominant legume fed to dairy cows in the United States.

Besides dietary factors, inconsistent responses to FPL may be related to animal factors. Numerous studies have examined the effects of alfalfa FPL, but most were designed using cows at a specific stage of lactation such as early lactation (Kononoff and Heinrichs, 2003) or mid lactation (Krause and Combs, 2003). However, cows respond differently to treatments depending on their level of intake (Voelker et al., 2002; Voelker Linton and Allen, 2008) and production (Oba and Allen, 1999). Because FPL and level of intake affect ruminal passage and digestion rates and, thus, digesta fill in the rumen, the response to effects of particle size and its relationship with intake level should be assessed to determine if responses to treatment vary among cows with a wide range in DMI. We hypothesized that responses of DMI and passage rates to legume particle length are related to level of intake, and shorter particle length would permit a greater increase in passage rate than longer particle length as feed intake increases.

The objectives of this experiment were to evaluate the relationships between voluntary DMI and effects of length of cut of legume silage on DMI, milk production, ruminal fermentation and pool sizes, and digestion and passage kinetics in lactating dairy cows. This study had 3 distinctive features to improve our understanding of the role of particle size and interpret its effect on animal responses. First, it allowed effects of the interaction between FPL and preliminary DMI (pDMI) to be evaluated. The use of pDMI, an index of nutrient demand, allowed the evaluation of treatments on animal responses in relation to level of intake and provided an indicator to test effects of intake level independent of treatments. Second, it directly compared treatment effects of long- and short-cut legume as the sole source of forage without the confounding effects of other dietary factors. Third, ruminal passage rates of individual feed fractions, instead of entire feeds, were measured using ruminally and duodenally cannulated cows.

\section{MATERIALS AND METHODS}

\section{Cows and Treatments}

Experimental procedures were approved by the Institutional Animal Care and Use Committee at Michigan State University. Thirteen multiparous Holstein cows from the Michigan State University Dairy Cattle Teaching and Research Center were assigned randomly to treatment sequence in a crossover design experiment with one 14-d preliminary period and two 19-d experimental periods. During the preliminary period, the first $10 \mathrm{~d}$ were allowed for diet adaptation, and samples were collected during the final $4 \mathrm{~d}$. During each experimental period, the first $12 \mathrm{~d}$ were allowed for diet adaptation and samples were collected during the final $7 \mathrm{~d}$. Cows were $177 \pm 66$ (mean \pm SD) DIM at the end of the preliminary period and were selected to provide a wide range and uniform distribution of pDMI and milk yield. During the final $4 \mathrm{~d}$ of the $14-\mathrm{d}$ preliminary period, the average pDMI among cows ranged from 22.8 to 32.4 $\mathrm{kg} / \mathrm{d}$ (mean $=26.5 \mathrm{~kg} / \mathrm{d})$ and $3.5 \%$ FCM yield ranged from 22.9 to $62.4 \mathrm{~kg} / \mathrm{d}$ (mean $=35.1 \mathrm{~kg} / \mathrm{d}$; Table 1). Prior to calving, cows were cannulated ruminally (Bar Diamond Inc., Parma, ID) and duodenally with a gutter-type $\mathrm{T}$ cannula placed approximately $10 \mathrm{~cm}$ distal to the pylorus (Joy et al., 1997). Surgery was performed at the Department of Large Animal Clinical Science, College of Veterinary Medicine, Michigan State University.

Experimental treatments were diets containing AL silage chopped to a theoretical length of cut (TLC) of either (1) $19 \mathrm{~mm}$ (long cut, LC) or (2) $10 \mathrm{~mm}$ (short cut, SC) as the sole forage. These TLC were selected to provide a wide interval within the normal range of TLC to examine if animal response to FPL is affected by level of feed intake.

Alfalfa was produced at the campus farm at Michigan State University (East Lansing), harvested from the same field using a New Holland FP230 pull-type forage harvester (New Holland, Racine, WI) set according to manufacturer specifications for theoretical lengths of cut of $19 \mathrm{~mm}$ and $10 \mathrm{~mm}$ for long- and short-cut AL, respectively, and ensiled in Ag-Bags (Ag-Bag Systems Inc., St. Nazianz, WI). During the sample collection periods, long- and short-cut AL contained approximately $43 \%$ NDF (DM basis; Table 2). Diets LC and SC were formulated to contain $21 \%$ forage NDF and $18 \%$ CP. The diet fed during the preliminary period was formulated so that long- and short-cut AL each contributed $50 \%$ of forage NDF. Diets also contained dry ground corn, soybean meal $(48 \% \mathrm{CP})$, SoyPLUS (West Central Soy Cooperative, Ralston, IA), vitaminmineral premix, limestone, and salt (Table 3). 
Table 1. Characterization of 13 cows during the final $4 \mathrm{~d}$ of the 14-d preliminary period, when cows were fed a common diet

\begin{tabular}{lccccc}
\hline Parameter & Median & Mean & SD & Minimum & Maximum \\
\hline Parity & 3 & 3.1 & 0.9 & 2 & 5 \\
BW, $^{1} \mathrm{~kg}$ & 609 & 612 & 61 & 508 & 750 \\
BCS & 2.75 & 2.7 & 0.5 & 1.9 & 3.6 \\
DIM & 202 & 177 & 66 & 50 & 250 \\
Milk, kg/d & 33.1 & 35.5 & 10.7 & 21.9 & 59.4 \\
$3.5 \% \mathrm{FCM}, \mathrm{kg} / \mathrm{d}$ & 34.4 & 35.1 & 10.4 & 22.9 & 62.4 \\
DMI, kg/d & 26.7 & 26.5 & 2.6 & 22.8 & 32.4 \\
\hline
\end{tabular}

${ }^{1}$ Empty BW (ruminal digesta removed).

\section{Data and Sample Collection}

Throughout the experiment, cows were housed in tie-stalls and fed diets as TMR once daily $(1130 \mathrm{~h})$ at $110 \%$ of expected intake. The amounts of feed offered and refused (orts) were weighed daily for each cow. Forage samples were collected twice weekly and analyzed to adjust diets to account for DM, NDF, and $\mathrm{CP}$ fluctuation. Samples of all dietary ingredients $(0.5$ $\mathrm{kg}$ ) and orts (12.5\%) were collected daily from d 11 to 14 during the preliminary period and d 13 to 17 during each experimental period. Samples were frozen immediately after collection at $-20^{\circ} \mathrm{C}$ and combined into one composite sample per period before analysis.

Cows were moved to an exercise lot twice daily (0230 and $1300 \mathrm{~h}$ ) before milking in a parlor (0400 and 1430 h). Milk yield was measured and milk was sampled at each milking on d 11 to 14 of the preliminary period and on d 13 to 17 of the experimental periods. Rumenempty BW was measured by weighing the cow after evacuation of ruminal digesta on d 14 of the preliminary period and d 19 of each experimental period. Body condition score was determined on the same days by 4 trained investigators blinded to treatments (Wildman et al., 1982; 5 -point scale, where $1=$ thin and $5=$ fat).

Duodenal samples (900 mL), fecal samples (500 g), rumen fluid and particulate samples for microbial isolation (400 g), and rumen fluid samples for $\mathrm{pH}$, concentrations of VFA, lactate, and ammonia $(100 \mathrm{~mL})$ were collected every $15 \mathrm{~h}$ from d 13 to 17 of each experimental period so that 8 samples were taken for each cow in each period, representing every $3 \mathrm{~h}$ of a 24 -h period to account for diurnal variation. Rumen fluid and particulate matter for microbial isolation were collected from the reticulum, near the reticular-omasal orifice, transported to the laboratory, and processed. Rumen fluid for $\mathrm{pH}$, VFA, lactate, and ammonia was obtained by combining digesta from 5 different sites in the rumen and straining it through nylon mesh $(\sim 1 \mathrm{~mm}$ pore size); fluid $\mathrm{pH}$ was recorded immediately. Samples were stored at $-20^{\circ} \mathrm{C}$.
Table 2. Chemical composition, particle size distribution, and fermentation parameters of the long-cut $(19 \mathrm{~mm})$ and short-cut (10 $\mathrm{mm}$ ) alfalfa silage included in the treatment diets

\begin{tabular}{|c|c|c|}
\hline \multirow[b]{2}{*}{ Item } & \multicolumn{2}{|c|}{ Alfalfa silage } \\
\hline & Long & Short \\
\hline \multicolumn{3}{|l|}{ Chemical composition } \\
\hline DM, \% & 42.2 & 36.9 \\
\hline OM, \% of DM & 92.0 & 90.9 \\
\hline $\mathrm{NDF}, \%$ of DM & 42.3 & 44.0 \\
\hline iNDF, ${ }^{1} \%$ of DM & 29.1 & 26.8 \\
\hline iNDF, $\%$ of NDF & 68.8 & 60.9 \\
\hline $\mathrm{ADF}, \%$ of $\mathrm{DM}$ & 36.5 & 37.2 \\
\hline ADF nitrogen, $\%$ of DM & 1.70 & 1.65 \\
\hline $\mathrm{ADL}, \%$ of DM & 8.91 & 9.05 \\
\hline $\mathrm{CP}, \%$ of DM & 20.4 & 19.6 \\
\hline Starch, \% of DM & 1.89 & 1.92 \\
\hline NDF digestibility, ${ }^{2} \%$ & 34.1 & 35.0 \\
\hline \multicolumn{3}{|l|}{ Particles size distribution $^{3}$} \\
\hline \multicolumn{3}{|l|}{ Wet sieving, \% DM retained } \\
\hline $19.0 \mathrm{~mm}$ & 23.2 & 8.57 \\
\hline $9.50 \mathrm{~mm}$ & 39.6 & 20.4 \\
\hline $4.75 \mathrm{~mm}$ & 21.0 & 30.3 \\
\hline $2.36 \mathrm{~mm}$ & 6.29 & 26.6 \\
\hline $1.18 \mathrm{~mm}$ & 3.49 & 6.14 \\
\hline $0.600 \mathrm{~mm}$ & 2.24 & 3.56 \\
\hline $0.300 \mathrm{~mm}$ & 1.86 & 1.93 \\
\hline $0.150 \mathrm{~mm}$ & 1.20 & 1.19 \\
\hline $0.075 \mathrm{~mm}$ & 0.76 & 0.88 \\
\hline $0.038 \mathrm{~mm}$ & 0.44 & 0.58 \\
\hline Mean particle size, ${ }^{4} \mathrm{~mm}$ & 14.1 & 8.1 \\
\hline \multicolumn{3}{|c|}{ Penn State Particle Separator, } \\
\hline$>19.0 \mathrm{~mm}$ & 33.2 & 10.7 \\
\hline 19.0 to $8.0 \mathrm{~mm}$ & 42.9 & 51.7 \\
\hline$<8.0 \mathrm{~mm}$ & 23.9 & 37.6 \\
\hline \multicolumn{3}{|l|}{ Fermentation } \\
\hline $\mathrm{pH}$ & 4.62 & 4.42 \\
\hline Acetic acid, $\%$ of DM & 1.29 & 1.49 \\
\hline Propionic acid, \% of DM & 0.08 & 0.07 \\
\hline Butyric acid, $\%$ of DM & $<0.01$ & $<0.01$ \\
\hline Lactic acid, $\%$ of DM & 5.40 & 6.46 \\
\hline Lactic:Acetic & 4.19 & 4.34 \\
\hline Ethanol, $\%$ of DM & 0.10 & 0.08 \\
\hline Ammonia, $\mathrm{m} M$ & 6.32 & 4.95 \\
\hline
\end{tabular}

${ }^{1} \mathrm{iNDF}=$ indigestible NDF.

${ }^{2}$ Thirty-hour in vitro NDF digestibility.

${ }^{3}$ Particle size distributions of silages were measured each period $(\mathrm{n}=$ 2).

${ }^{4}$ Mean particle size calculated from particle size distribution determined by wet sieving. 
Table 3. Ingredients and chemical composition of preliminary and treatment diets (as analyzed) containing either long-cut $(19 \mathrm{~mm})$ or short-cut $(10 \mathrm{~mm})$ alfalfa silage as the sole source of forage

\begin{tabular}{lccc}
\hline Item & Preliminary & Long & Short \\
\hline Ingredients, \% of DM & & & \\
Alfalfa silage, long cut & 23.2 & 46.3 & 47.0 \\
Alfalfa silage, short cut & 23.2 & - & 36.0 \\
Dry ground corn & 36.4 & 36.4 & 7.84 \\
Soybean meal (48\% CP) & 7.99 & 8.03 & 3.92 \\
SoyPLUS 1 Vyitamin mineral mix ${ }^{2}$ & 4.00 & 4.02 & 4.68 \\
Limestone & 4.68 & 4.68 & 0.39 \\
Salt & 0.39 & 0.39 & 0.19 \\
Chemical composition & 0.19 & 0.19 & 53.5 \\
DM, \% & & & 92.8 \\
OM, \% of DM & 53.1 & 58.8 & 25.5 \\
NDF, \% of DM & 93.4 & 93.4 & 20.7 \\
\% forage NDF & 26.9 & 24.5 & 81.1 \\
\% NDF from forage & 21.7 & 19.6 & 14.6 \\
iNDF, \% of DM & 80.9 & 80.0 & 57.3 \\
iNDF, \% of NDF & NA & 15.5 & 18.9 \\
CP, \% of DM & NA & 63.2 & 30.5 \\
Starch, \% of DM & 18.0 & 19.3 & \\
\hline
\end{tabular}

${ }^{1}$ West Central Soy Cooperative (Ralston, IA).

${ }^{2}$ Vitamin mineral mix contained (DM basis) $17.1 \%$ sodium bicarbonate, $3.9 \%$ dicalcium phosphate, $2.6 \%$ magnesium oxide, $1.9 \%$ salt, $1.9 \%$ trace mineral premix, $0.4 \%$ vitamin $\mathrm{A}, 0.4 \%$ vitamin $\mathrm{D}, 0.2 \%$ vitamin $\mathrm{E}$, and $71.6 \%$ dry ground corn as a carrier.

${ }^{3} \mathrm{iNDF}=$ indigestible NDF.

${ }^{4} \mathrm{NA}=$ no analysis for preliminary diet.

Ruminal contents were evacuated manually through the ruminal cannula $4.5 \mathrm{~h}$ after feeding at the beginning of $\mathrm{d} 18(1600 \mathrm{~h})$, and $41.5 \mathrm{~h}$ later, $2 \mathrm{~h}$ before feeding at the end of $\mathrm{d} 19(0930 \mathrm{~h})$ for each experimental period. Total rumen content mass and volume were determined. To ensure accurate sampling, every tenth handful of digesta (10\%) was separated for a subsample throughout evacuation. This subsample was squeezed into primarily solid and liquid phases. Both phases were weighed and sampled $(350 \mathrm{~mL})$ for determination of nutrient pool size. All samples were stored at $-20^{\circ} \mathrm{C}$.

\section{Sample Analysis and Calculations}

Milk yields recorded at each milking were summed for a daily total, which were averaged for each period. Milk samples were analyzed for fat, true protein, lactose, and SNF with infrared spectroscopy by Michigan DHIA (East Lansing). Yields of 3.5\% FCM and milk components were calculated using milk yield and component concentrations for each milking, summed for a daily total, and averaged for each period.

Forage samples were combined to 1 composite sample per forage per period. Particle size distribution was determined using the Penn State Particle Separator containing 2 sieves (19 and $8 \mathrm{~mm}$ ) and a pan (Lammers et al., 1996). In addition, samples were wet sieved manually and sequentially through screens with the following aperture sizes: 19.0, 9.50, 4.75, 2.36, 1.18, 0.600,
$0.300,0.150,0.075$, and $0.038 \mathrm{~mm}$. The fraction of DM retained on the screens from wet sieving was used to calculate mean particle size.

Diet ingredients, orts, and feces were lyophilized (TriPhilizer MP, FTS Systems, Stone Ridge, NY). All dried samples were ground with a Wiley mill (1-mm screen; Arthur H. Thomas, Philadelphia, PA). Dried, ground fecal samples were combined on an equal DM basis into 1 sample per cow per period. Frozen duodenal samples for each cow period $(\mathrm{n}=8)$ were chopped finely using a commercial food processor (84142 Food Cutter, Hobart Manufacturing Co., Troy, $\mathrm{OH}$ ) and subsampled in the frozen state to obtain representative samples. These duodenal subsamples and the $350 \mathrm{~mL}$ of ruminal solid and liquid samples were lyophilized and ground as described above. Dried ruminal solid and liquid samples were recombined according to the original ratio of solid and liquid DM.

Samples were analyzed for ash, NDF, indigestible NDF (iNDF), ADF, acid detergent sulfuric acid lignin (ADL), ADF nitrogen (forages only), CP, and starch. Ash concentration was determined after $5 \mathrm{~h}$ of combustion at $500^{\circ} \mathrm{C}$ in a muffle furnace. Concentrations of NDF were determined according to Mertens (2002) and $\mathrm{ADF}$ and ADL according to Goering and Van Soest (1970). Forage samples were analyzed for ADF nitrogen by Cumberland Valley Analytical Services Inc. (Hagerstown, MD) using ADF method 973.18 (AOAC, 2000), modified for using glass micro-fiber filter with $1.5 \mu \mathrm{m}$ 
particle retention in place of fritted glass crucible, and followed by nitrogen analysis of ADF residue using a Leco FP-528 Nitrogen Combustion Analyzer (Leco, St. Joseph, MI). Indigestible NDF was estimated as NDF residue after a 240-h in vitro fermentation (Goering and Van Soest, 1970); flasks were reinoculated at 120 $\mathrm{h}$ to ensure a viable microbial population. Forage NDF digestibility was determined by $30-\mathrm{h}$ in vitro fermentation (Goering and Van Soest, 1970). Ruminal fluid for the in vitro incubations was collected from a nonpregnant dry cow fed dry hay only. Fraction of potentially digestible NDF (pdNDF) was calculated by difference $(1.00$ - iNDF). Crude protein was analyzed according to Hach et al. (1987). Starch was measured by an enzymatic method (Karkalas, 1985) after samples were gelatinized with sodium hydroxide. Glucose concentration was measured using a glucose oxidase method (Glucose kit \#510, Sigma Chemical Co., St. Louis, MO), and absorbance was determined with a micro-plate reader (SpectraMax 190, Molecular Devices Corp., Sunnyvale, CA). Concentrations of all nutrients except DM were expressed as percentages of DM determined by drying at $105^{\circ} \mathrm{C}$ in forced-air oven for more than $8 \mathrm{~h}$.

Duodenal digesta were analyzed for purines and ammonia to estimate microbial $\mathrm{N}$ (MN) flow and nonammonia, nonmicrobial N (NANMN) flow to the duodenum. Purine concentration was used as a microbial marker, and purine-to-MN ratio was estimated by analysis of microbial pellets obtained by differential centrifugation of the rumen fluid and particulate samples collected near the reticulum. Rumen fluid and particulate matter were blended, strained through nylon mesh, and the liquid portion was centrifuged at 500 $\times g$ for $15 \mathrm{~min}$. The supernatant was centrifuged at $18,000 \times g$ for $15 \mathrm{~min}$, and the pellet was washed with $0.9 \% \mathrm{NaCl}$ solution and centrifuged again at 18,000 $\times g$ for $15 \mathrm{~min}$, resuspended in water, and lyophilized. Total purines were measured by spectrophotometer (Beckman Instruments Inc., Fullerton, CA) at $260 \mathrm{~nm}$ according to Zinn and Owens (1986). Ammonia concentration was determined for centrifuged duodenal and rumen fluid samples according to Broderick and Kang (1980). Rumen fluid was also analyzed for concentrations of major VFA and lactate by HPLC (Waters Corp., Milford, MA) according to Oba and Allen (2003).

Dry matter and nutrient intakes were calculated using the composition of feed offered and refused. Ruminal pool sizes $(\mathrm{kg})$ of OM, NDF, iNDF, pdNDF, starch, $\mathrm{MN}$, and NANMN were determined by multiplying the concentration of each component in rumen samples by the ruminal digesta DM mass $(\mathrm{kg})$. Duodenal flows $(\mathrm{kg} / \mathrm{d})$ of DM, OM, total NDF, pdNDF, starch, MN, NANMN, and ammonia $\mathrm{N}$ were determined using iNDF as a flow marker; iNDF intake $(\mathrm{kg} / \mathrm{d})$ was multiplied by the ratio between the component and iNDF in duodenal digesta. Duodenal flow of microbial OM was determined using the purines-to-OM ratio (Oba and Allen, 2003), and true ruminally digested OM was calculated by subtracting duodenal flow of nonmicrobial OM from OM intake. Indigestible NDF was used as an internal marker to estimate nutrient digestibility in the rumen and in the total tract (Cochran et al., 1986). Turnover rate in the rumen, passage rate from the rumen, and ruminal digestion rate of each component was calculated by using the following equations:

Turnover rate $(\% / \mathrm{h})=100 \times($ intake of component/ ruminal pool of component)/24;

Passage rate $(\% / \mathrm{h})=100 \times($ duodenal flow

of component/ruminal pool of component)/24; and

Digestion rate $(\% / \mathrm{h})=$ turnover rate in the rumen

$(\% / \mathrm{h})$ - passage rate from the rumen $(\% / \mathrm{h})$.

\section{Statistical Analysis}

All data were analyzed by using the fit model procedure of JMP (version 8, SAS Institute Inc., Cary, NC). To determine differences between treatments and evaluate interactions of treatment with DMI, where pDMI (calculated as the mean of DMI values on d 11 to 14 of the 14-d preliminary period) was used as the covariate for treatment responses, data were analyzed according to the following model:

$$
\begin{gathered}
\mathrm{Y}_{\mathrm{ijk}}=\mu+\mathrm{C}_{\mathrm{i}}+\mathrm{P}_{\mathrm{j}}+\mathrm{T}_{\mathrm{k}}+\mathrm{PT}_{\mathrm{jk}}+\mathrm{pDMI}+\mathrm{T}_{\mathrm{k}} \mathrm{pDMI} \\
+\mathrm{pDMI}^{2}+\mathrm{T}_{\mathrm{k}} \mathrm{PDMI}^{2}+\mathrm{e}_{\mathrm{ijk}},
\end{gathered}
$$

where $Y_{\mathrm{ijk}}$ is the the dependent variable, $\mu$ is the overall mean, $\mathrm{C}_{\mathrm{i}}$ is the random effect of cow ( $\mathrm{i}=1$ to 13$), \mathrm{P}_{\mathrm{j}}$ is the fixed effect of period ( $\mathrm{j}=1$ to 2 ), $\mathrm{T}_{\mathrm{k}}$ is the fixed effect of treatment ( $\mathrm{k}=1$ to 2 ), $\mathrm{PT}_{\mathrm{jk}}$ is the interaction of period and treatment, pDMI is the linear effect of $\mathrm{pDMI}, \mathrm{T}_{\mathrm{k}} \mathrm{pDMI}$ is the interaction of treatment and $\mathrm{pDMI}$ (linear), $\mathrm{pDMI}^{2}$ is the quadratic effect of $\mathrm{pDMI}$, $\mathrm{T}_{\mathrm{k}} \mathrm{pDMI}^{2}$ is the interaction of treatment and $\mathrm{pDMI}$ (quadratic), and $\mathrm{e}_{\mathrm{ijk}}$ is the residual error. Statistical significance for $\mathrm{T}_{\mathrm{k}} \mathrm{pDMI}$ and $\mathrm{T}_{\mathrm{k}} \mathrm{pDMI}{ }^{2}$ indicated that treatment differences were related to pDMI. Covariate and interaction terms were removed stepwise from the model if $P>0.20$. Treatment effects and their interaction (linear and quadratic relationships) were declared significant at $P \leq 0.05$ and $P \leq 0.10$, respectively. Ten- 
dencies for treatment effects and their interactions were declared at $P \leq 0.10$ and $P \leq 0.15$, respectively.

Sixteen cows started the experiment; however, 2 cows were removed during the experiment (one cow injured a teat and the other cow went off feed). Additionally, data from one cow were excluded before statistical analysis because she ate sporadically and had inconsistent DMI, which ranged from 12.3 to $21.7 \mathrm{~kg} / \mathrm{d}$ during the $4 \mathrm{~d}$ collection of the preliminary period and from 2.7 to $26.0 \mathrm{~kg} / \mathrm{d}$ and 17.5 to $24.2 \mathrm{~kg} / \mathrm{d}$ during the 5 -d collection of the first and second experimental periods, respectively. Data from 13 cows were statistically analyzed for all response variables except those associated with $\mathrm{N}$ metabolism (Table 11), which included 12 cows. One cow (with the highest pDMI) was considered an outlier based on large Cook's distance values (Cook and Weisberg, 1982) for response variables for MN flux and microbial efficiency only. This indicated a problem with the partitioning of NANMN and MN due to purine concentration for this cow; however, all $\mathrm{N}$ data from this cow were removed.

\section{RESULTS AND DISCUSSION}

\section{Comparison of Forages and Diets}

Physical characteristics of AL are listed in Table 2. Forages chopped to a TLC of 19 and $10 \mathrm{~mm}$ had mean particle sizes of 14.1 and $8.1 \mathrm{~mm}$, respectively. The proportion of particles $>19 \mathrm{~mm}$ was 22.5 percentage units higher (33.2 vs. 10.7\%) and that of particles $<8$ mm was 13.7 percentage units lower (23.9 vs. $37.6 \%$ ) for long-cut than for short-cut AL, respectively.

Chemical analyses (Table 2) showed that AL with different lengths of cut had similar concentrations of $\mathrm{OM}, \mathrm{ADF}, \mathrm{ADL}, \mathrm{CP}$, and starch. Long-cut AL had higher DM concentration than short-cut AL due to the longer wilting time for long-cut AL as the silages were sequentially harvested, and long-cut AL was mowed, chopped, and ensiled last. Indigestible NDF expressed as a percentage of total NDF was high for both silages. Despite AL silages being harvested from the same field on the same day, the proportion of iNDF of total NDF was 7.9 percentage units higher for long-cut than short-cut because concentration of total NDF was 1.7 percentage units lower and iNDF was 2.3 percentage units higher for long-cut AL compared with short-cut AL. Although the iNDF concentration was higher for long-cut AL compared with short-cut AL, in vitro NDF digestibility $(30 \mathrm{~h})$ of long-cut AL was only 0.9 percentage units lower than that of short-cut AL. It is possible that the drier, longer particles of long-cut AL did not pack as densely as the wetter, shorter particles of short-cut AL, which might have affected fermenta- tion and storage; however, this was not evident based on the chemical analyses or fermentation profile. The ADF nitrogen concentrations, a measure of indigestible compounds formed by chemically linked protein and carbohydrate used as an indicator of heat-damaged protein, were low and similar for both cuts of AL, and they appeared to undergo favorable fermentation and be well preserved based on the low $\mathrm{pH}$ and the production of mainly lactic acid.

Diet ingredients and chemical composition are shown in Table 3. The preliminary diet contained similar proportions of forage NDF from long- and short-cut AL. Both treatment diets had a 47:53 forage:concentrate ratio, contained approximately $20 \%$ forage NDF and had similar OM, CP, and starch composition, which was mathematically calculated according to the proportion of each feed ingredient in the diet and its respective analytical values. The $\mathrm{LC}$ diet had approximately 1 percentage unit lower total NDF and higher iNDF than the SC diet, which resulted in the proportion of iNDF of total dietary NDF being 5.9 percentage units higher for LC. Differences in DM concentration in diets were because of the different DM concentrations of the forages. The calculated concentrations of total NDF in LC and SC and forage NDF in LC were slightly lower than the formulated targets but similar to NRC (2001) minimum requirements. In both diets, forage NDF provided nearly $80 \%$ of the total diet NDF.

\section{Effects of Legume FPL and pDMI}

Results of AL particle length and its interaction with pDMI on milk yields and composition are shown in Table 4. Response of milk fat concentration to FPL was related to pDMI, as indicated by a significant interaction between FPL and pDMI (interaction $P=0.01$ ); LC decreased milk fat concentration more per kilogram of pDMI increase than did SC (Figure 1). This effect on concentration of milk fat influenced other treatment by $\mathrm{pDMI}$ interactions, including milk fat yield (interaction $P=0.006$ ), FCM yield (interaction $P=0.03$ ), and efficiency (FCM/DMI; interaction $P=0.06)$; LC increased these responses less per kilogram of pDMI increase than did SC. The aforementioned interactions resulted in a greater benefit for $\mathrm{LC}$ for cows with low pDMI and a greater benefit for SC for cows with high pDMI.

The LC diet tended to decrease DMI (26.3 vs. 27.2 $\mathrm{kg} / \mathrm{d} ; P=0.10$, Table 4) compared with the SC diet. We expected LC to be more filling than SC, causing greater rumen distention and potentially limiting DMI, particularly in cows with high DMI for which ruminal distension is more likely to limit feed intake (Allen, 1996). Oba and Allen (1999) and Voelker et al. (2002) 
Table 4. Milk production and composition, feed intake, and BW change of cows fed treatment diets containing either long-cut (19 mm) or short-cut $(10 \mathrm{~mm})$ alfalfa silage as the sole source of forage

\begin{tabular}{|c|c|c|c|c|c|c|c|c|c|}
\hline \multirow[b]{2}{*}{ Item } & \multicolumn{2}{|c|}{ Treatment LSM } & \multirow[b]{2}{*}{$\mathrm{SE}$} & \multicolumn{6}{|c|}{$P$-value ${ }^{1}$} \\
\hline & Long & Short & & Trt & $\begin{array}{l}\text { Trt } \times \\
\text { Period }\end{array}$ & $\mathrm{pDMI}$ & $\begin{array}{l}\text { Trt } \times \\
\text { pDMI }\end{array}$ & $\begin{array}{c}\mathrm{pDMI} \times \\
\mathrm{pDMI}\end{array}$ & $\begin{array}{c}\text { Trt } \times \text { pDMI } \\
\times \text { pDMI }\end{array}$ \\
\hline \multicolumn{10}{|l|}{ Yield, $\mathrm{kg} / \mathrm{d}$} \\
\hline Milk & 37.7 & 37.4 & 3.3 & 0.67 & $\mathrm{NS}^{2}$ & 0.03 & NS & 0.04 & NS \\
\hline $\mathrm{FCM}(3.5 \%)$ & 38.8 & 38.8 & 3.2 & 0.88 & NS & 0.03 & 0.03 & 0.06 & NS \\
\hline Milk fat & 1.28 & 1.29 & 0.09 & 0.57 & 0.08 & 0.11 & 0.006 & NS & NS \\
\hline $\mathrm{SNF}$ & 3.01 & 2.99 & 0.26 & 0.67 & NS & 0.02 & NS & 0.03 & NS \\
\hline \multicolumn{10}{|l|}{ Milk composition, \% } \\
\hline Fat & 3.77 & 3.80 & 0.15 & 0.58 & NS & 0.08 & 0.01 & 0.05 & NS \\
\hline Protein & 3.24 & 3.26 & 0.13 & 0.38 & NS & 0.32 & NS & 0.09 & NS \\
\hline Lactose & 4.86 & 4.87 & 0.07 & 0.41 & NS & 0.003 & NS & 0.005 & NS \\
\hline SNF & 7.98 & 8.01 & 0.09 & 0.14 & NS & 0.18 & NS & NS & NS \\
\hline DMI, $\mathrm{kg} / \mathrm{d}$ & 26.3 & 27.2 & 0.5 & 0.10 & NS & $<0.001$ & 0.34 & 0.03 & 0.18 \\
\hline
\end{tabular}

${ }^{1} P$-values for treatment $($ Trt $)$, Trt by period interaction $($ Trt $\times$ Period), preliminary DMI $(\mathrm{pDMI})$, Trt by pDMI interaction $($ Trt $\times \mathrm{pDMI})$, quadratic effect of $\mathrm{pDMI}(\mathrm{pDMI} \times \mathrm{pDMI})$, and Trt by quadratic effect of $\mathrm{pDMI}($ Trt $\times \mathrm{pDMI} \times \mathrm{pDMI})$.

${ }^{2}$ Nonsignificant, with $P>0.20$; term was removed from the statistical model.

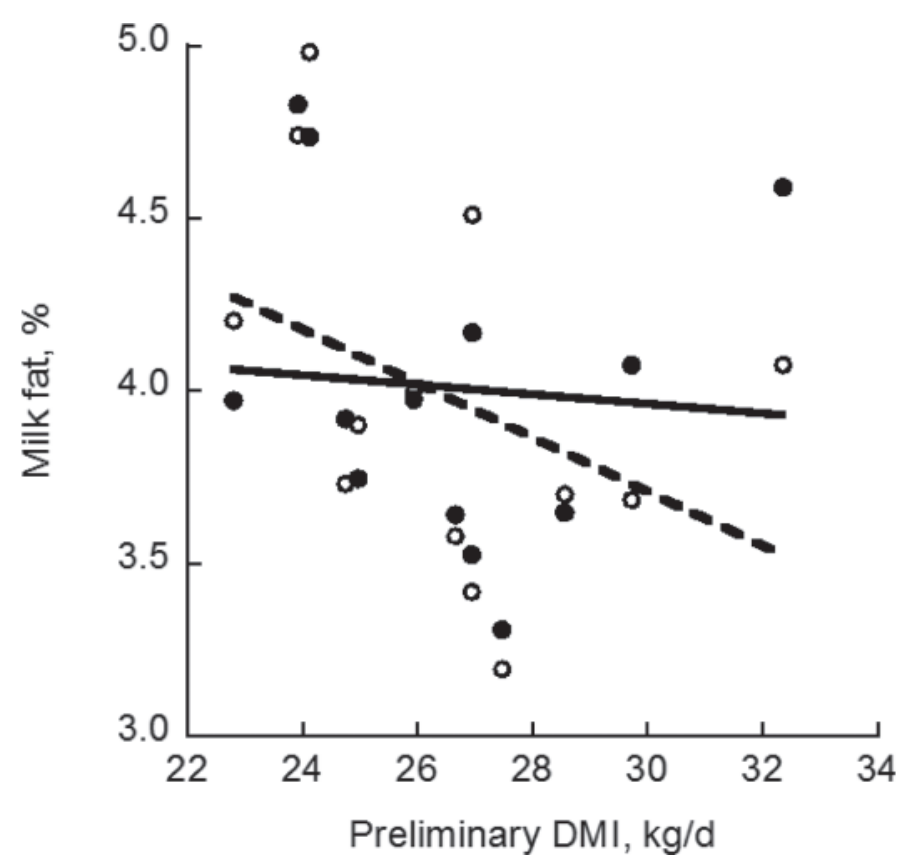

Figure 1. Interaction of long (19 mm; open circles, dashed line) and short (10 mm; closed circles, solid line) alfalfa particle length with preliminary DMI for milk fat concentration (interaction: $P=0.01$ linear; long: $P=0.18, \mathrm{R}^{2}=0.15$; short: $\left.P=0.80, \mathrm{R}^{2}=0.01\right)$. The preliminary DMI on the $\mathrm{x}$-axis are the mean DMI of individual cows during the final $4 \mathrm{~d}$ of the preliminary period when all cows were fed a common diet. The best-fit lines are drawn to demonstrate the significant interaction even if the individual relationships are not significant. found DMI responses to a more filling diet varied by production level, which is generally correlated with DMI (NRC, 2001), where DMI was increasingly limited by high-fill diets compared with low-fill diets as milk yield increased. We expected LC to slow rates of ruminal passage but FPL and its interaction with pDMI did not affect the rates of pdNDF, iNDF, or starch passage from the rumen (Table 5).

The LC diet tended to decrease the rate of ruminal turnover of NDF (4.68 vs. $4.91 \% / \mathrm{h} ; P=0.09$, Table $5)$ compared with the $\mathrm{SC}$ diet. Despite the slower turnover rate of NDF for LC, the rumen pool of NDF was less for LC compared with SC except for cows with the lowest or highest DMI (interaction $P=0.08$, quadratic; Figure 2A). This indicated that the faster NDF turnover rate was not sufficient to counterbalance the higher DMI for SC, resulting in larger NDF rumen pools for SC than LC. Additionally, rumen digesta wet weight (interaction $P=0.03$, quadratic; Figure $2 \mathrm{~B}$ ) and volume (interaction $P=0.006$, quadratic; Figure $2 \mathrm{C}$ ) were related to pDMI (Table 6); rumen digesta wet weight and volume were less for LC compared with SC except for cows at the low and high ends of the pDMI range. Although the effect of treatment on DMI was not related to $\mathrm{pDMI}$ (interaction $P \geq 0.18$ ), a visual examination of a graph with pDMI and DMI (Figure $2 \mathrm{D})$ illustrated that the difference in DMI between LC and SC was small for cows with low pDMI but the difference became greater as pDMI increased and then narrowed for cows with high pDMI. Because LC had less rumen digesta mass and volume than SC for cows 
Table 5. Rumen kinetics of cows fed treatment diets containing either long-cut (19 mm) or short-cut (10 mm) alfalfa silage as the sole source of forage

\begin{tabular}{|c|c|c|c|c|c|c|c|c|c|}
\hline Item & \multicolumn{2}{|c|}{ Treatment LSM } & $\mathrm{SE}$ & \multicolumn{6}{|c|}{$P$-value ${ }^{1}$} \\
\hline $\mathrm{DM}$ & 11.0 & 10.8 & 0.3 & 0.59 & 0.03 & $\mathrm{NS}^{2}$ & NS & NS & NS \\
\hline $\mathrm{OM}$ & 11.2 & 11.0 & 0.3 & 0.61 & 0.04 & NS & NS & NS & NS \\
\hline NDF & 4.68 & 4.91 & 0.16 & 0.09 & 0.08 & NS & NS & NS & NS \\
\hline \multicolumn{10}{|l|}{ Ruminal turnover time, $\mathrm{h}$} \\
\hline DM & 9.28 & 9.36 & 0.26 & 0.77 & 0.02 & NS & NS & NS & NS \\
\hline $\mathrm{OM}$ & 9.09 & 9.16 & 0.27 & 0.81 & 0.03 & NS & NS & NS & NS \\
\hline NDF & 21.9 & 20.6 & 0.7 & 0.10 & 0.07 & NS & NS & NS & NS \\
\hline pdNDF & 7.58 & 6.75 & 0.58 & 0.34 & NS & 0.24 & NS & 0.15 & NS \\
\hline $\mathrm{iNDF}^{4}$ & 30.3 & 31.0 & 1.2 & 0.55 & 0.16 & NS & NS & NS & NS \\
\hline Starch & 2.08 & 2.11 & 0.15 & 0.85 & 0.006 & NS & NS & NS & NS \\
\hline \multicolumn{10}{|l|}{ Ruminal passage rate, $\% / \mathrm{h}$} \\
\hline pdNDF & 12.3 & 14.7 & 2.3 & 0.51 & NS & NS & NS & NS & NS \\
\hline Starch & 33.3 & 31.4 & 3.4 & 0.56 & 0.05 & 0.62 & NS & 0.18 & NS \\
\hline
\end{tabular}

${ }^{1} P$-values for treatment (Trt), Trt by period interaction (Trt $\times$ Period), preliminary DMI (pDMI), Trt by pDMI interaction $($ Trt $\times$ pDMI), quadratic effect of pDMI $(\mathrm{pDMI} \times \mathrm{pDMI})$, and Trt by quadratic effect of $\mathrm{pDMI}($ Trt $\times \mathrm{pDMI} \times \mathrm{pDMI})$.

${ }^{2}$ Nonsignificant, with $P>0.20$; term was removed from the statistical model.

${ }^{3} \mathrm{pdNDF}=$ potentially digestible NDF.

${ }^{4} \mathrm{iNDF}=$ indigestible $\mathrm{NDF}$.

with the greatest reduction in DMI, it is unlikely that DMI for LC was limited by rumen fill.

Feeding behavior was measured in another experiment of similar design (Kammes and Allen, 2012) evaluating the effects of grass FPL. Similarly, cows consumed 0.9 $\mathrm{kg} / \mathrm{d}$ less (21.8 vs. $22.7 \mathrm{~kg} / \mathrm{d}$ ) when fed diets with longcut compared with short-cut grass silage. Total chewing time was greater for cows consuming long-cut than short-cut grass silage diets, such that cows consuming long-cut grass silage were approaching maximum chewing times reported in the literature (Tafaj et al., 2007). Feeding behavior was not measured in this study, but DMI for cows consuming LC might have been limited by chewing time.

Treatment interacted quadratically with pDMI to affect site of starch digestion (Table 7). True ruminal starch digestion $(\mathrm{kg} / \mathrm{d}$, interaction $P=0.13$, quadratic) and digestibility (\%, interaction $P=0.09$, quadratic; Figure 3A) were lower for LC compared with SC for cows with low and high pDMI. As a result, starch flux from the rumen to duodenum (interaction $P=0.05$, quadratic; Figure 3B) was greater for LC compared with SC for cows with low and high pDMI. Postruminal starch digestion $(\mathrm{kg} / \mathrm{d}$, interaction $P=0.05$, quadratic) followed a similar pattern as starch flux, and postruminal starch digestibility (\%, interaction $P=0.08$, qua- dratic; Figure 3C) had a pattern that was the inverse of true ruminal starch digestibility. Although the cow at each end of the pDMI range $(<23$ and $>32 \mathrm{~kg}$ of $\mathrm{DM} / \mathrm{d}$ ) was not identified as an outlier based on Cook's distance values (Cook and Weisberg, 1982), both cows amplified the quadratic effects. Therefore, data were statistically reanalyzed after the 2 cows were removed. Removal did not eliminate the quadratic effects or notably change results and conclusions so data from both cows were included; however, caution should be used when making inferences.

As pDMI increased, LC increased ruminal digestibility of pdNDF and SC decreased it (interaction $P=$ 0.10 ; Table 8). Ruminal digestibility of NDF was lower for LC compared with SC $(P=0.01$; Table 8$)$, and the differences were greater for cows with lower pDMI (interaction $P=0.09$; Figure 4$)$. Total-tract digestibilities of pdNDF (63.5 vs. $78.0 \%, P=0.009)$ and $\mathrm{NDF}(23.7$ vs. $34.0 \%, P<0.001)$ were lower for LC than for SC (Table 8). The lower digestibility of NDF for LC may be due, in part, to the higher concentration of iNDF for long-cut AL than for short-cut AL (Table 2), despite being harvested from the same field and having similar ensiling characteristics as previously discussed.

Total-tract digestibilities of NDF (and pdNDF) were lower than ruminal digestibility because negative 

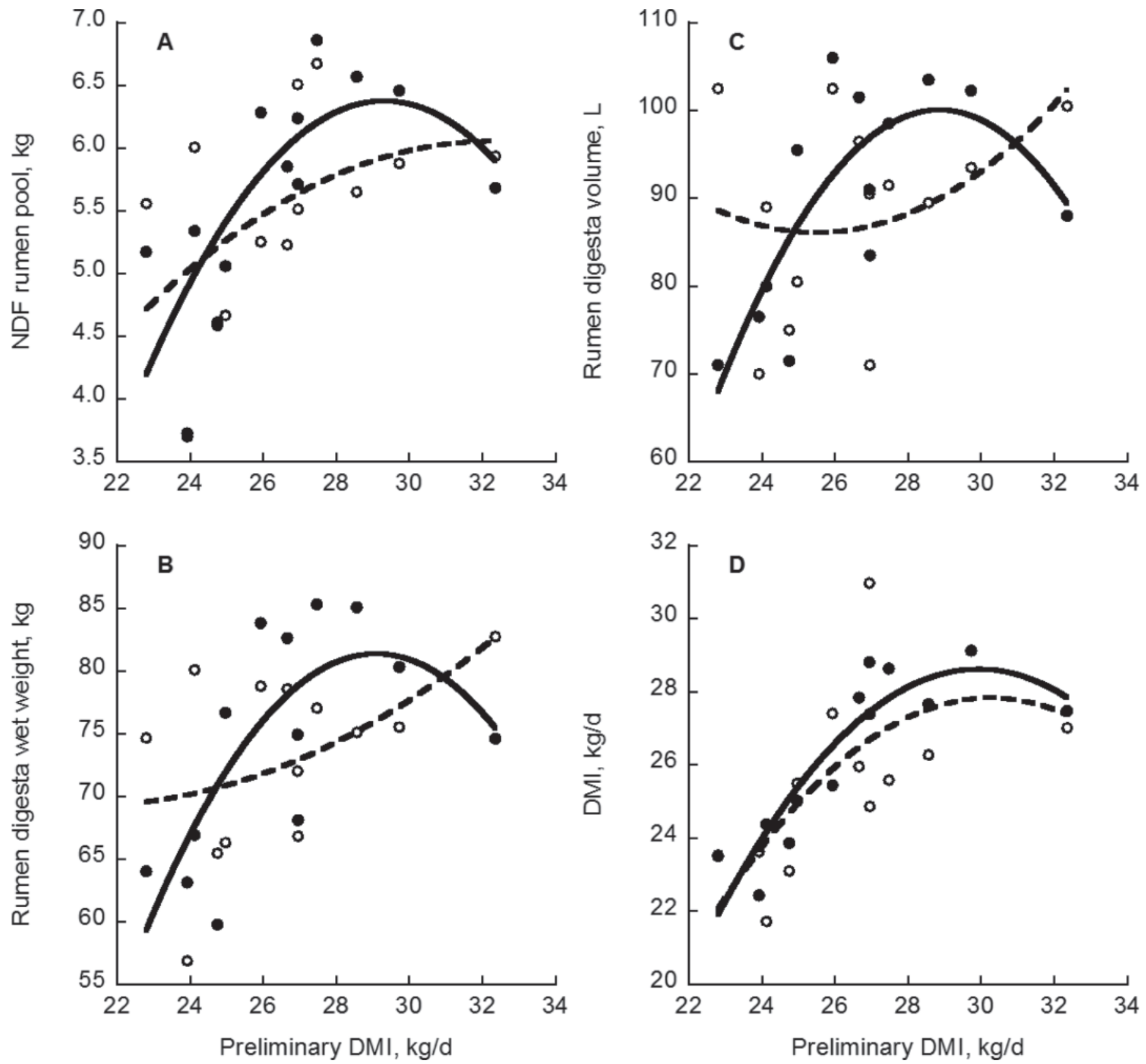

Figure 2. Interaction of long (19 mm; open circles, dashed line) and short (10 mm; closed circles, solid line) alfalfa particle length with preliminary DMI for (A) NDF rumen pool (interaction: $P=0.08$ quadratic; long: $P=0.25, \mathrm{R}^{2}=0.24$; short: $P=0.02, \mathrm{R}^{2}=0.57$ ), (B) rumen digesta wet weight (interaction: $P=0.03$ quadratic; long: $P=0.25, \mathrm{R}^{2}=0.24$; short: $P=0.02, \mathrm{R}^{2}=0.55$ ), $(\mathrm{C})$ rumen digesta volume (interaction: $P=0.006$ quadratic; long: $P=0.43, \mathrm{R}^{2}=0.15$; short: $P=0.009, \mathrm{R}^{2}=0.61$ ), and (D) DMI (interaction: not significant; long: $P=0.04$, $\mathrm{R}^{2}=0.48$; short: $P<0.001, \mathrm{R}^{2}=0.82$ ). The preliminary DMI on the $\mathrm{x}$-axis are the mean DMI of individual cows during the final $4 \mathrm{~d}$ of the preliminary period when all cows were fed a common diet. The best-fit lines are drawn to demonstrate the significant interaction even if the individual relationships are not significant.

postruminal digestibilities were calculated for NDF (and pdNDF) in the present experiment. We evaluated $\mathrm{Cr}_{2} \mathrm{O}_{3}[5 \mathrm{~g}$ dosed through the ruminal cannula at 8-h intervals (total of $15 \mathrm{~g}$ of $\mathrm{Cr}_{2} \mathrm{O}_{3} / \mathrm{d}$ ) from d 6 to d 17 with a priming dose of $2 \times$ on $\mathrm{d} 6]$, ADL, and acid detergent peroxide lignin (Cochran et al., 1988) as alternative flow markers. Based on comparisons of calculated flow data using different markers, iNDF provided the most reasonable results and was used as flow marker. The lower digestibility for total tract than in the rumen is 
Table 6. Rumen pools of cows fed treatment diets containing either long-cut $(19 \mathrm{~mm})$ or short-cut $(10 \mathrm{~mm})$ alfalfa silage as the sole source of forage

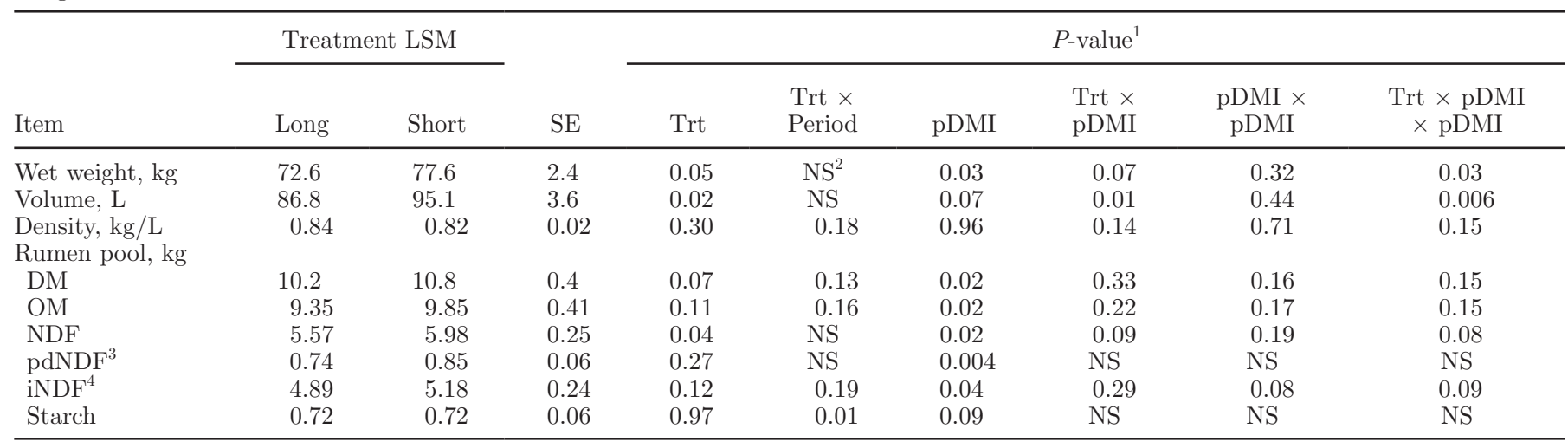

${ }^{1} P$-values for treatment $($ Trt $)$, Trt by period interaction $($ Trt $\times$ Period), preliminary DMI $(\mathrm{pDMI})$, Trt by pDMI interaction $($ Trt $\times$ pDMI), quadratic effect of $\mathrm{pDMI}(\mathrm{pDMI} \times \mathrm{pDMI})$, and Trt by quadratic effect of $\mathrm{pDMI}($ Trt $\times \mathrm{pDMI} \times \mathrm{pDMI})$.

${ }^{2}$ Nonsignificant, with $P>0.20$; term was removed from the statistical model.

${ }^{3} \mathrm{pdNDF}=$ potentially digestible NDF.

${ }^{4} \mathrm{iNDF}=$ indigestible NDF

due to a net gain of fiber from the duodenum to the feces, which has previously been reported with both the gutter-type $\mathrm{T}$ duodenal cannula (Huhtanen and Jaakkola, 1993; Poore et al., 1993), the type used in this study, and closed T-type duodenal cannula (Stensig and Robinson, 1997). The underestimation of duodenal NDF flow or duodenal iNDF:NDF ratio using iNDF as a marker creates inaccuracies of estimated flow of duodenal fiber and postruminal digestibility. These errors may be related to unrepresentative digesta sampling due to differential separation of fluid and particles relative to the true material flowing out of the duo- denum or analytical problems in fiber determination of duodenal samples possibly due to a component in the duodenal digesta that interferes with the analysis. Although absolute values are not biologically reasonable, relative comparisons between treatments within the same experiment are useful.

Due to NDF digestibility, LC decreased total-tract digestibility of DM (65.6 vs. $67.6 \%, P=0.04)$ and $\mathrm{OM}$ (66.6 vs. $68.6 \%, P=0.03)$ and total-tract digestion of DM (17.3 vs. $18.2 \mathrm{~kg} / \mathrm{d}, P=0.01)$ and $\mathrm{OM}(16.4$ vs. $17.2 \mathrm{~kg} / \mathrm{d}, P=0.02$ ) compared with SC (Table 9 ). Interaction of treatment and pDMI for true ruminal

Table 7. Starch digestion of cows fed treatment diets containing either long-cut $(19 \mathrm{~mm})$ or short-cut $(10 \mathrm{~mm})$ alfalfa silage as the sole source of forage

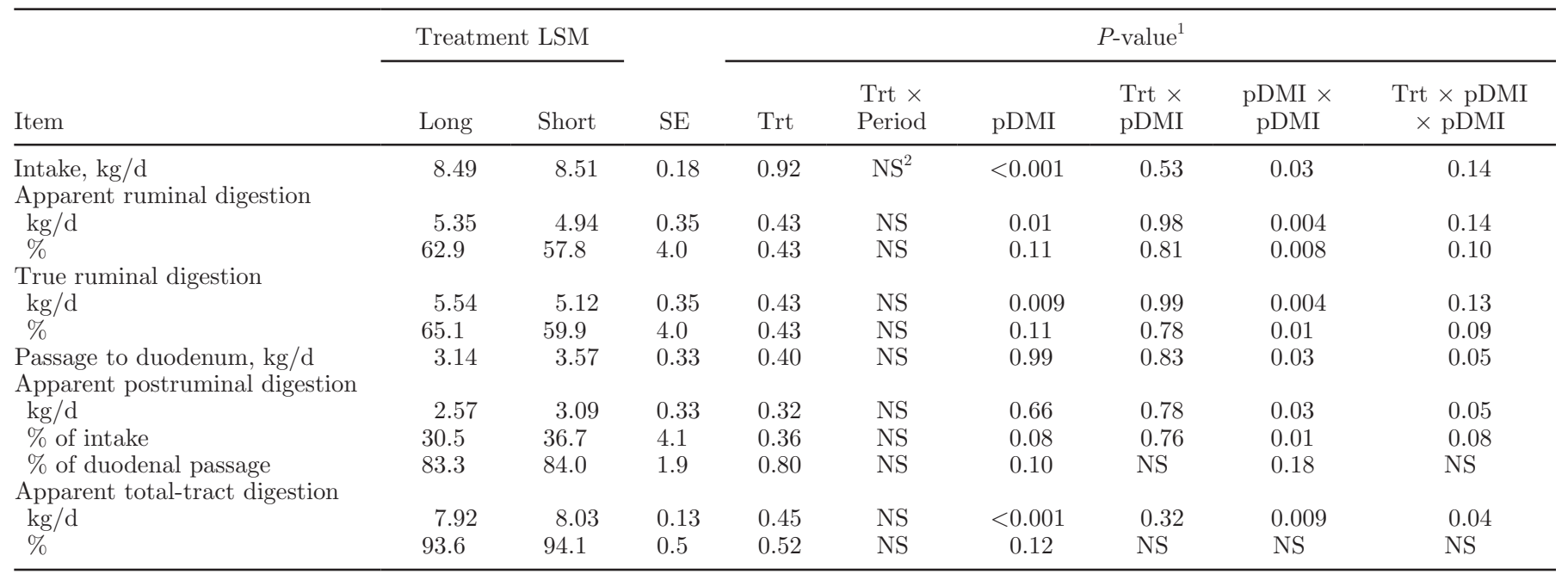

${ }^{1} P$-values for treatment (Trt), Trt by period interaction (Trt $\times$ Period), preliminary DMI (pDMI), Trt by preliminary pDMI interaction $($ Trt $\times$ $\mathrm{pDMI})$, quadratic effect of $\mathrm{pDMI}(\mathrm{pDMI} \times \mathrm{pDMI})$, and Trt by quadratic effect of $\mathrm{pDMI}($ Trt $\times \mathrm{pDMI} \times \mathrm{pDMI})$.

${ }^{2}$ Nonsignificant, with $P>0.20$; term was removed from the statistical model. 

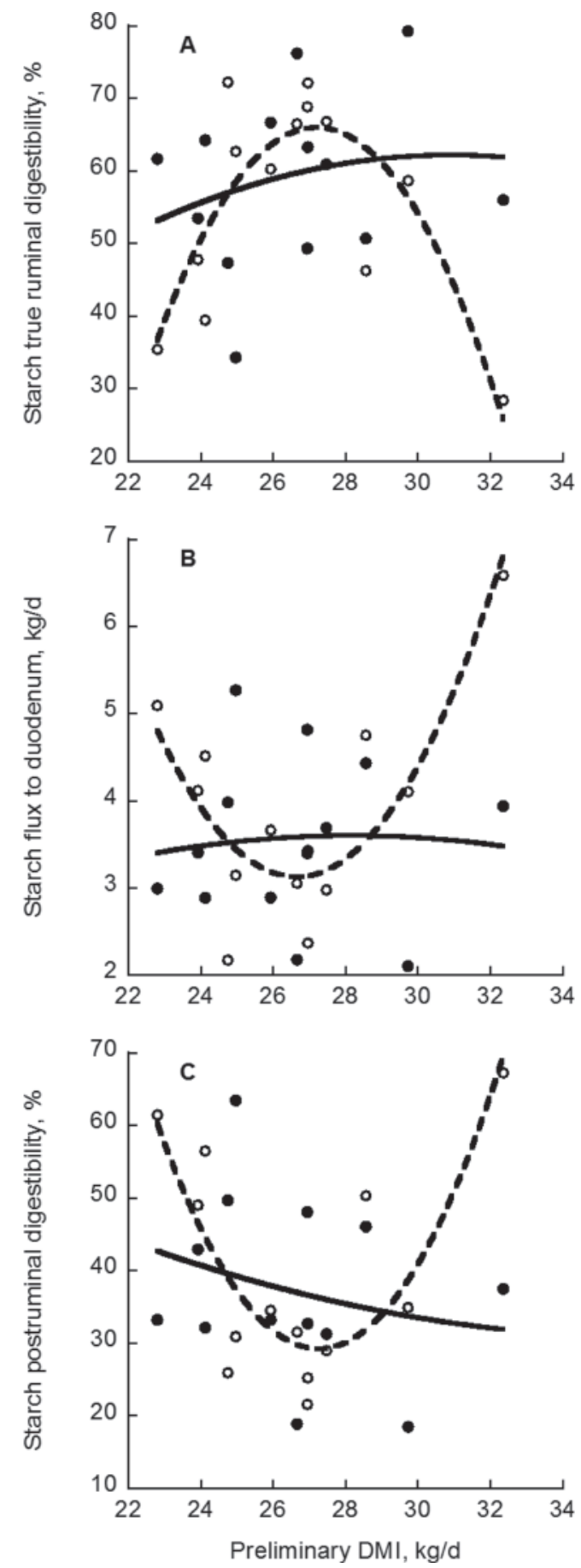

Figure 3. Interaction of long (19 mm; open circles, dashed line) and short (10 mm; closed circles, solid line) alfalfa particle length with preliminary DMI for starch (A) true ruminal digestibility (interaction: $P=0.09$ quadratic; long: $P=0.002, \mathrm{R}^{2}=0.71$; short: $P=0.77, \mathrm{R}^{2}$ $=0.05$ ), (B) flux from the rumen to duodenum (interaction: $P=0.05$ quadratic; long: $P=0.002, \mathrm{R}^{2}=0.72$; short: $\left.P=0.98, \mathrm{R}^{2}=0.004\right)$, and $(\mathrm{C})$ postruminal digestibility (interaction: $P=0.08$ quadratic; long: $P=0.002, \mathrm{R}^{2}=0.70$; short: $\left.P=0.74, \mathrm{R}^{2}=0.06\right)$. The preliminary DMI on the $\mathrm{x}$-axis are the mean DMI of individual cows during the final $4 \mathrm{~d}$ of the preliminary period when all cows were fed a common diet. The best-fit lines are drawn to demonstrate the significant interaction even if the individual relationships are not significant.
OM digestion $(\mathrm{kg} / \mathrm{d}$, interaction $P=0.11$, quadratic $)$ and digestibility $(\%$, interaction $P=0.03$, quadratic; Table 9) were due to effects on starch digestion (Table 7, Figure 3).

Although differences in ruminal digestion were detected, FPL and its interaction with pDMI did not affect rumen $\mathrm{pH}(P>0.19)$, which was 6.26 for $\mathrm{LC}$ and $\mathrm{SC}$, or total VFA concentration $(P>0.48$; Table 10$)$. However, LC tended to increase concentrations of butyrate (19.2 vs. $18.3 \mathrm{mM}, P=0.06)$ and valerate $(2.32$ vs. $2.20 \mathrm{mM}, P=0.06$ ) compared with SC (Table 10).

\section{Effects of pDMI on Ruminal Passage Rates}

Experimental data on rates of passage from the rumen, particularly for individual feed fractions, are scarce. Given the effect of passage on ruminal digestibility and pool sizes and microbial growth, quantitative knowledge on rates of nutrient passage from the rumen are needed to better understand nutrient availability in ruminants and improve nutrition models. Furthermore, because passage rates from the rumen generally increase with increased intake, measurements of ruminal passage rates of nutrients over a wide range of DMI are necessary. We measured the effects of DMI on rates of passage of feed fractions from the rumen using the pool and flux method (Robinson et al., 1987).

We expected ruminal passage rates to increase with pDMI, but passage rates of pdNDF, iNDF, and starch were not related to level of intake either independent of or dependent upon treatment (Table 5). These results are consistent with the previously mentioned experiment of similar design evaluating the effects of grass FPL (Kammes and Allen, 2012). Although passage rates were not related to $\mathrm{pDMI}$ in either study, rates of ruminal digestion of starch and pdNDF were related to $\mathrm{pDMI}$ in that study, which were not observed in the present experiment.

\section{Effects of Treatment and pDMI on N Flux and Microbial Efficiency}

Flux of NANMN passed from the rumen to the duodenum was related to $\mathrm{pDMI}$, which increased at a slower rate for $\mathrm{LC}$ than for $\mathrm{SC}$ (interaction $P=0.03$; Figure 5). The increase in NANMN flux contributed to increased NAN flux as pDMI increased (interaction $P$ $=0.02$; Table 11), as level of intake did not affect $\mathrm{MN}$ flux. Despite the increase in NAN flux with greater intake, postruminal digestion $(\mathrm{g} / \mathrm{d})$ and digestibility (\%) were not related to $\mathrm{pDMI}$ (interaction $P \geq 0.21$; Table 11). When expressed as a percentage of duodenal NAN, NANMN and MN fluxes to the duodenum were related to pDMI (interaction $P=0.008$; Table 11). As 


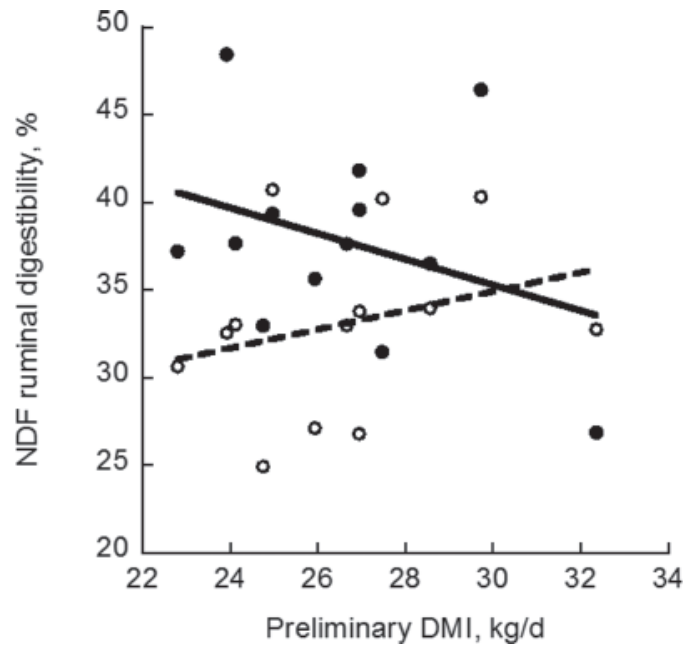

Figure 4. Interaction of long (19 mm; open circles, dashed line) and short (10 mm; closed circles, solid line) alfalfa particle length with preliminary DMI for NDF ruminal digestibility (interaction: $P=0.09$ linear; long: $P=0.36, \mathrm{R}^{2}=0.08$; short: $\left.P=0.27, \mathrm{R}^{2}=0.11\right)$. The preliminary DMI on the $\mathrm{x}$-axis are the mean DMI of individual cows during the final $4 \mathrm{~d}$ of the preliminary period when all cows were fed a common diet. The best-fit lines are drawn to demonstrate the significant interaction even if the individual relationships are not significant.
pDMI increased, LC decreased NANMN flux and SC increased it (Figure 6A), and the reverse was observed for MN flux (Figure 6B). Microbial N flux was highly related to the rate of ruminal digestion of starch for LC $\left(P=0.004, \mathrm{R}^{2}=0.71\right)$ but not $\mathrm{SC}(P=0.78$, $\mathrm{R}^{2}=0.05$; Figure $\left.7 \mathrm{~A}\right)$. Similarly, MN flux was highly related to true ruminal $\mathrm{OM}$ digestion $(\mathrm{kg} / \mathrm{d})$ for $\mathrm{LC}$ $\left(P=0.002, \mathrm{R}^{2}=0.75\right)$ but not $\mathrm{SC}\left(P=0.25, \mathrm{R}^{2}=\right.$ 0.26 ; Figure $7 \mathrm{~B}$ ). Microbial efficiency was not related to level of intake either independent of or dependent upon treatment $(P \geq 0.25$; Table 11$)$. The LC diet tended to increase ruminal ammonia concentration (16.4 vs. 14.3 $\mathrm{mg} / \mathrm{dl}, P=0.06$; Table 11) compared with SC. Despite being drier, long-cut AL had higher ammonia (6.32 vs. $4.95 \mathrm{~m} M$, Table 2) than short-cut AL, which may be the source for the greater ruminal ammonia concentration observed for cows consuming the LC diet.

\section{CONCLUSIONS}

In addition to treatment differences in particle length, forages differed in iNDF concentration (iNDF as a proportion of total NDF was 7.9 percentage units higher for long-cut AL than for short-cut AL) for unknown reasons, despite our efforts to prevent potentially con-

Table 8. Neutral detergent fiber digestion of cows fed treatment diets containing either long-cut (19 mm) or short-cut (10 mm) alfalfa silage as the sole source of forage

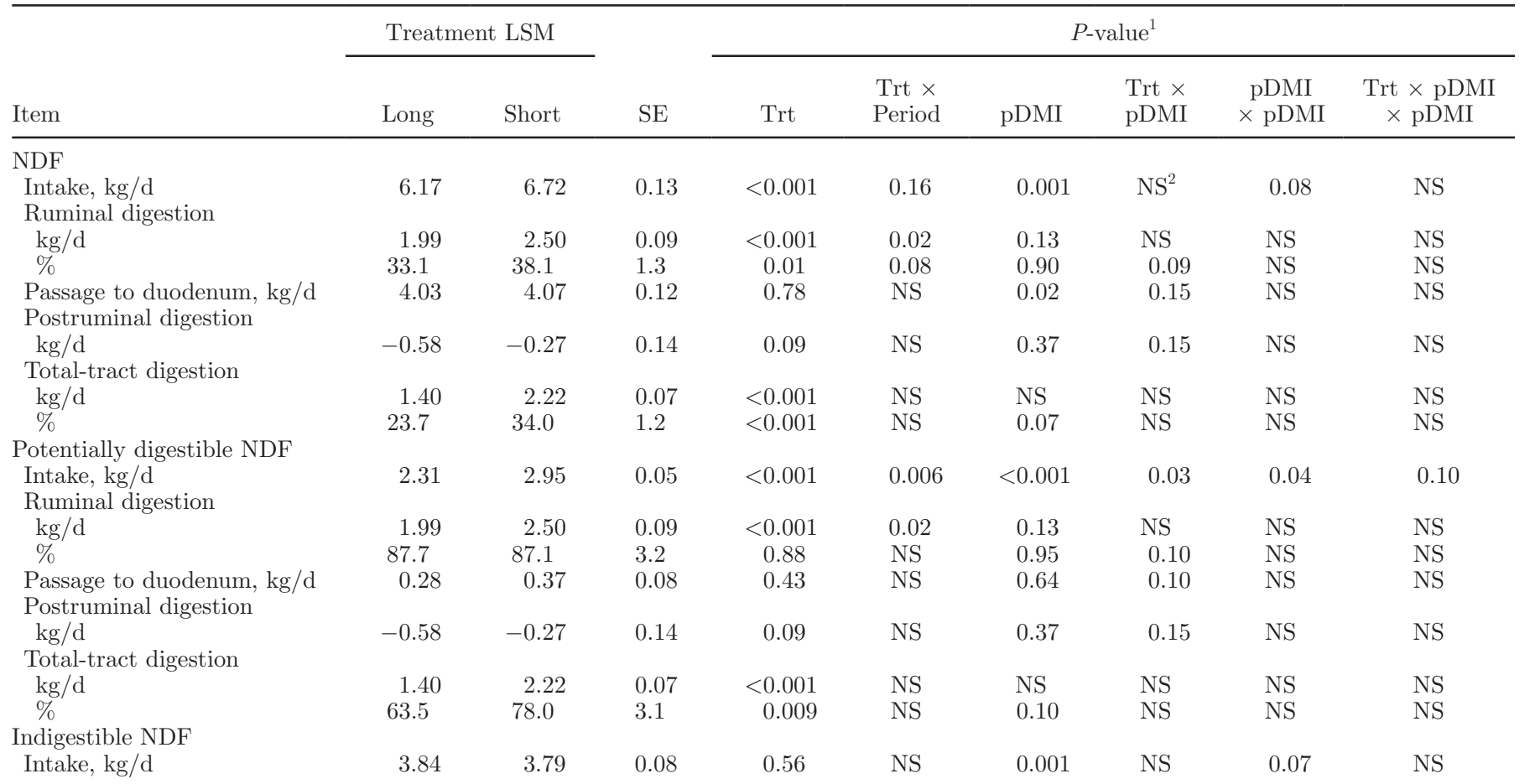

${ }^{1} P$-values for treatment $($ Trt $)$, Trt by period interaction $($ Trt $\times$ Period), preliminary DMI $(\mathrm{pDMI})$, Trt by pDMI interaction $($ Trt $\times \mathrm{pDMI})$, quadratic effect of $\mathrm{pDMI}(\mathrm{pDMI} \times \mathrm{pDMI})$, and Trt by quadratic effect of $\mathrm{pDMI}($ Trt $\times \mathrm{pDMI} \times \mathrm{pDMI})$.

${ }^{2}$ Nonsignificant, with $P>0.20$; term was removed from the statistical model. 
Table 9. Dry matter and OM digestion of cows fed treatment diets containing either long-cut (19 mm) or short-cut (10 mm) alfalfa silage as the sole source of forage

\begin{tabular}{|c|c|c|c|c|c|c|c|c|c|}
\hline \multirow[b]{2}{*}{ Item } & \multicolumn{2}{|c|}{ Treatment LSM } & \multirow[b]{2}{*}{$\mathrm{SE}$} & \multicolumn{6}{|c|}{$P$-value ${ }^{1}$} \\
\hline & Long & Short & & Trt & $\begin{array}{l}\text { Trt } \times \\
\text { Period }\end{array}$ & pDMI & $\begin{array}{l}\text { Trt } \times \\
\text { pDMI }\end{array}$ & $\begin{array}{l}\text { pDMI } \\
\times \text { pDMI }\end{array}$ & $\begin{array}{c}\text { Trt } \times \mathrm{pDMI} \\
\times \mathrm{pDMI}\end{array}$ \\
\hline Intake, $\mathrm{kg} / \mathrm{d}$ & 26.3 & 27.2 & 0.5 & 0.10 & $\mathrm{NS}^{2}$ & $<0.001$ & 0.34 & 0.03 & 0.18 \\
\hline \multicolumn{10}{|l|}{ Apparent total-tract digestion } \\
\hline $\mathrm{kg} / \mathrm{d}$ & 17.3 & 18.2 & 0.3 & 0.01 & 0.13 & $<0.001$ & NS & 0.02 & NS \\
\hline Intake, $\mathrm{kg} / \mathrm{d}$ & 24.6 & 25.3 & 0.5 & 0.18 & NS & $<0.001$ & 0.36 & 0.03 & 0.18 \\
\hline \multicolumn{10}{|l|}{ Apparent ruminal digestion } \\
\hline $\mathrm{kg} / \mathrm{d}$ & 11.6 & 11.8 & 0.4 & 0.65 & NS & 0.002 & NS & $<0.001$ & NS \\
\hline$\%$ & 47.8 & 45.8 & 1.8 & 0.47 & NS & 0.17 & 0.32 & 0.004 & 0.18 \\
\hline \multicolumn{10}{|l|}{ True ruminal digestion } \\
\hline $\mathrm{kg} / \mathrm{d}$ & 15.2 & 14.9 & 0.6 & 0.68 & NS & 0.005 & 0.51 & 0.006 & 0.11 \\
\hline$\%$ & 61.8 & 58.9 & 1.9 & 0.31 & NS & 0.21 & 0.21 & 0.01 & 0.03 \\
\hline $\mathrm{kg} / \mathrm{d}$ & 16.4 & 17.2 & 0.2 & 0.02 & 0.11 & $<0.001$ & NS & 0.01 & NS \\
\hline$\%$ & 66.6 & 68.6 & 0.5 & 0.03 & NS & 0.05 & NS & NS & NS \\
\hline
\end{tabular}

${ }^{1} P$-values for treatment $($ Trt $)$, Trt by period interaction $($ Trt $\times$ Period), preliminary DMI $(\mathrm{pDMI})$, Trt by pDMI interaction $($ Trt $\times \mathrm{pDMI})$, quadratic effect of $\mathrm{pDMI}(\mathrm{pDMI} \times \mathrm{pDMI})$, and Trt by quadratic effect of $\mathrm{pDMI}($ Trt $\times \mathrm{pDMI} \times \mathrm{pDMI})$.

${ }^{2}$ Nonsignificant, with $P>0.20$; term was removed from the statistical model.

founding errors. Legume particle length and its interaction with $\mathrm{pDMI}$ did not affect milk yield or rumen $\mathrm{pH}$. The LC diet decreased milk fat concentration more per kilogram of pDMI increase and increased yields of milk fat and fat-corrected milk less per kilogram of pDMI increase than did the SC diet. The LC diet tended to decrease DMI compared with the SC diet. Ruminal digestion and passage rates of feed fractions did not differ between LC and SC and were not related to level of intake. The $\mathrm{LC}$ diet tended to decrease rate of ruminal turnover for NDF but increased NDF rumen pools at a slower rate than the SC diet as pDMI increased. This indicated that the faster NDF turnover rate was not sufficient to counterbalance the higher DMI for SC, resulting in larger NDF rumen pools for SC than LC. As pDMI increased, LC increased ruminal digestibilities

Table 10. Ruminal VFA concentrations and $\mathrm{pH}$ of cows fed treatment diets containing either long-cut (19 mm) or short-cut (10 mm) alfalfa silage as the sole source of forage

\begin{tabular}{|c|c|c|c|c|c|c|c|c|c|}
\hline \multirow[b]{2}{*}{ Item } & \multicolumn{2}{|c|}{ Treatment LSM } & \multirow[b]{2}{*}{$\mathrm{SE}$} & \multicolumn{6}{|c|}{$P$-value ${ }^{1}$} \\
\hline & Long & Short & & Trt & $\begin{array}{l}\text { Trt } x \\
\text { Period }\end{array}$ & $\mathrm{pDMI}$ & $\begin{array}{l}\text { Trt } \times \\
\text { pDMI }\end{array}$ & $\begin{array}{c}\mathrm{pDMI} \\
\times \mathrm{pDMI}\end{array}$ & $\begin{array}{c}\text { Trt } \times \text { pDMI } \\
\times \text { pDMI }\end{array}$ \\
\hline Acetate & 84.4 & 84.8 & 1.3 & 0.57 & NS & NS & NS & NS & NS \\
\hline Propionate & 29.9 & 29.3 & 0.6 & 0.40 & 0.03 & 0.04 & NS & NS & NS \\
\hline Butyrate & 19.2 & 18.3 & 0.4 & 0.06 & 0.05 & 0.11 & NS & NS & NS \\
\hline Valerate & 2.32 & 2.20 & 0.05 & 0.06 & NS & NS & NS & NS & NS \\
\hline Isovalerate & 2.10 & 2.13 & 0.09 & 0.78 & NS & 0.55 & 0.15 & NS & NS \\
\hline Branched-chain VFA ${ }^{3}$ & 3.54 & 3.50 & 0.12 & 0.82 & NS & NS & NS & NS & NS \\
\hline Acetate:Propionate & 2.85 & 2.90 & 0.04 & 0.32 & 0.008 & 0.08 & NS & NS & NS \\
\hline Ruminal pH & 6.26 & 6.26 & 0.04 & 0.99 & 0.01 & 0.06 & 0.94 & 0.86 & 0.19 \\
\hline
\end{tabular}

${ }^{1} P$-values for treatment (Trt), Trt by period interaction (Trt $\times$ Period), preliminary DMI $(\mathrm{pDMI})$, Trt by pDMI interaction $($ Trt $\times \mathrm{pDMI})$, quadratic effect of $\mathrm{pDMI}(\mathrm{pDMI} \times \mathrm{pDMI})$, and Trt by quadratic effect of $\mathrm{pDMI}($ Trt $\times \mathrm{pDMI} \times \mathrm{pDMI})$.

${ }^{2}$ Nonsignificant, with $P>0.20$; term was removed from the statistical model.

${ }^{3}$ Branched-chain VFA include isobutyrate and isovalerate. 


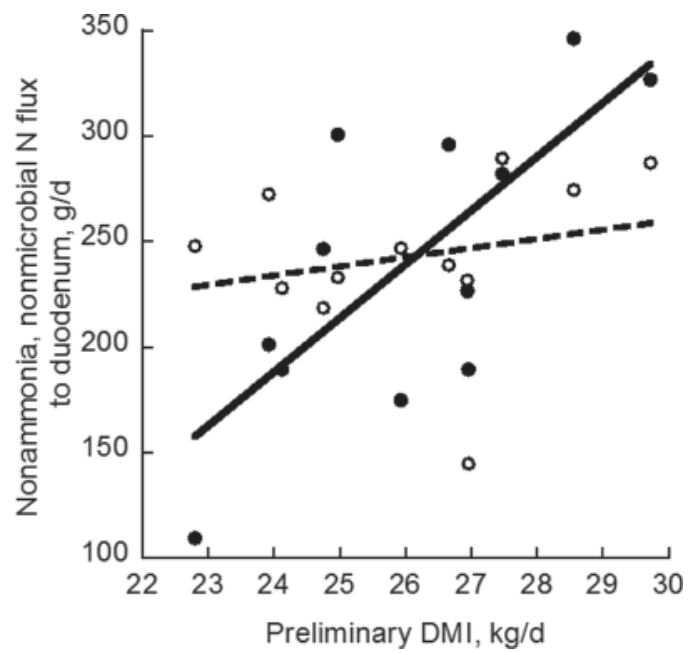

Figure 5. Interaction of long (19 mm; open circles, dashed line) and short (10 mm; closed circles, solid line) alfalfa particle length with preliminary DMI for nonammonia, nonmicrobial $\mathrm{N}$ flux from the rumen to duodenum (interaction: $P=0.03$ linear; long: $P=0.48, \mathrm{R}^{2}$ $=0.05$; short: $\left.P=0.007, \mathrm{R}^{2}=0.53\right)$. The preliminary DMI on the $\mathrm{x}-$ axis are the mean DMI of individual cows during the final $4 \mathrm{~d}$ of the preliminary period when all cows were fed a common diet. The best-fit lines are drawn to demonstrate the significant interaction even if the individual relationships are not significant. of pdNDF and total NDF and SC decreased them, but total-tract digestibilities of pdNDF, total NDF, OM, and DM were lower for LC than SC. When legume silage was the only source of forage in the diet, increasing the chop length from 10 to $19 \mathrm{~mm}$ tended to decrease DMI but did not negatively affect productivity of cows.

\section{ACKNOWLEDGMENTS}

This project was supported by National Research Initiative Competitive Grant no. 2006-35206-16708 from the USDA National Institute of Food and Agriculture (Washington, DC). The authors thank N. K. Ames (Department of Large Animal Clinical Science, College of Veterinary Medicine, Michigan State University), for performing duodenal and ruminal cannulation surgeries; D. G. Main and R. A. Longuski (both of Department of Animal Science, Michigan State University), R. E. Kreft and the staff of the Michigan State University Dairy Cattle Teaching and Research Center (East Lansing) for their technical assistance and support; and West Central Soy Cooperative (Ralston, IA) for donating the SoyPLUS protein supplement.

Table 11. Nitrogen metabolism of cows fed treatment diets containing either long-cut $(19 \mathrm{~mm})$ or short-cut (10 mm) alfalfa silage as the sole source of forage

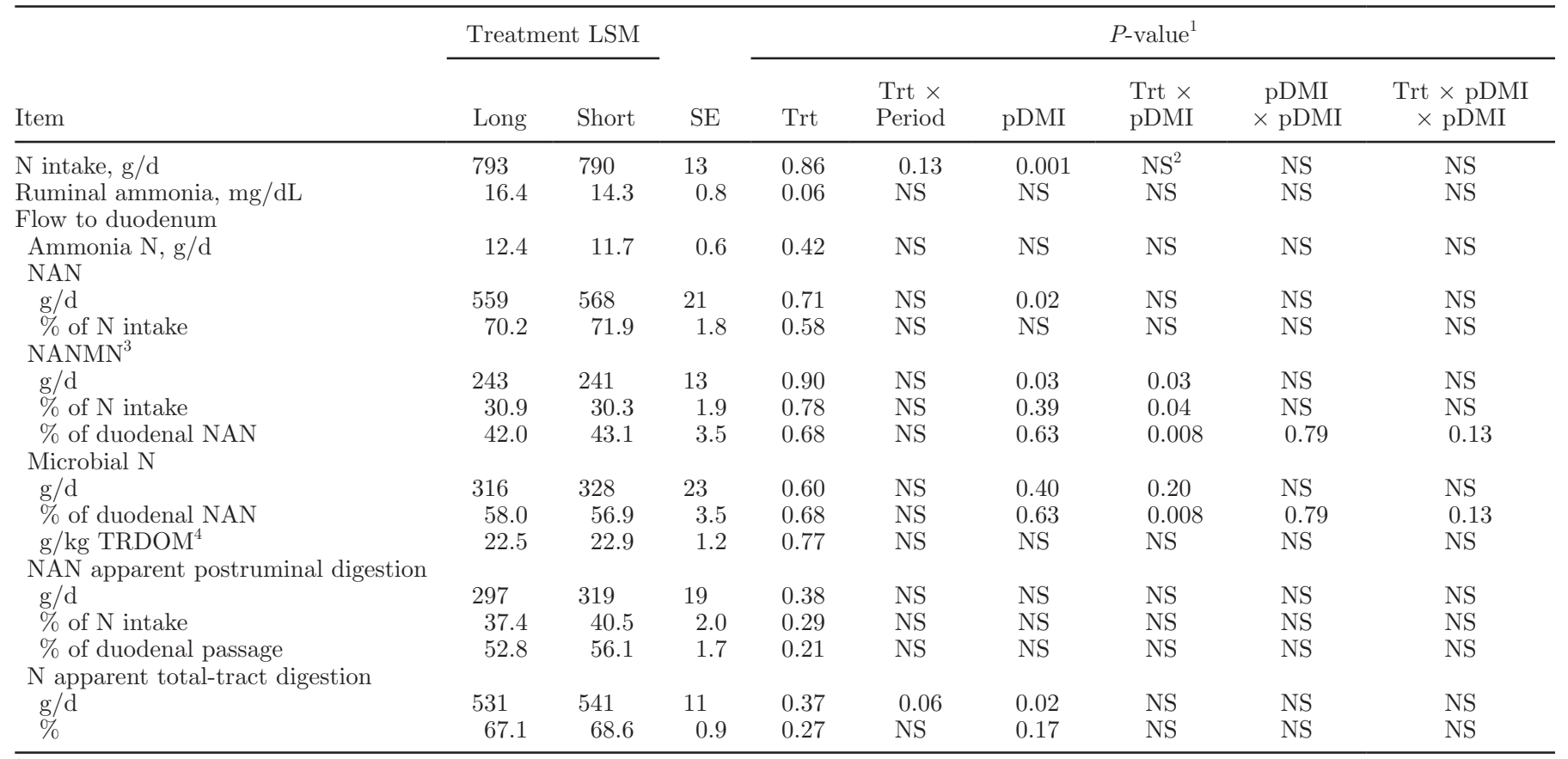

${ }^{1} P$-values for treatment (Trt), Trt by period interaction (Trt $\times$ Period), preliminary DMI (pDMI), Trt by pDMI interaction $($ Trt $\times$ pDMI), quadratic effect of pDMI $(\mathrm{pDMI} \times \mathrm{pDMI})$, and Trt by quadratic effect of $\mathrm{pDMI}($ Trt $\times \mathrm{pDMI} \times \mathrm{pDMI})$.

${ }^{2}$ Nonsignificant, with $P>0.20$; term was removed from the statistical model.

${ }^{3} \mathrm{NANMN}=$ nonammonia, nonmicrobial nitrogen.

${ }^{4} \mathrm{TRDOM}=$ true ruminally digested OM. 

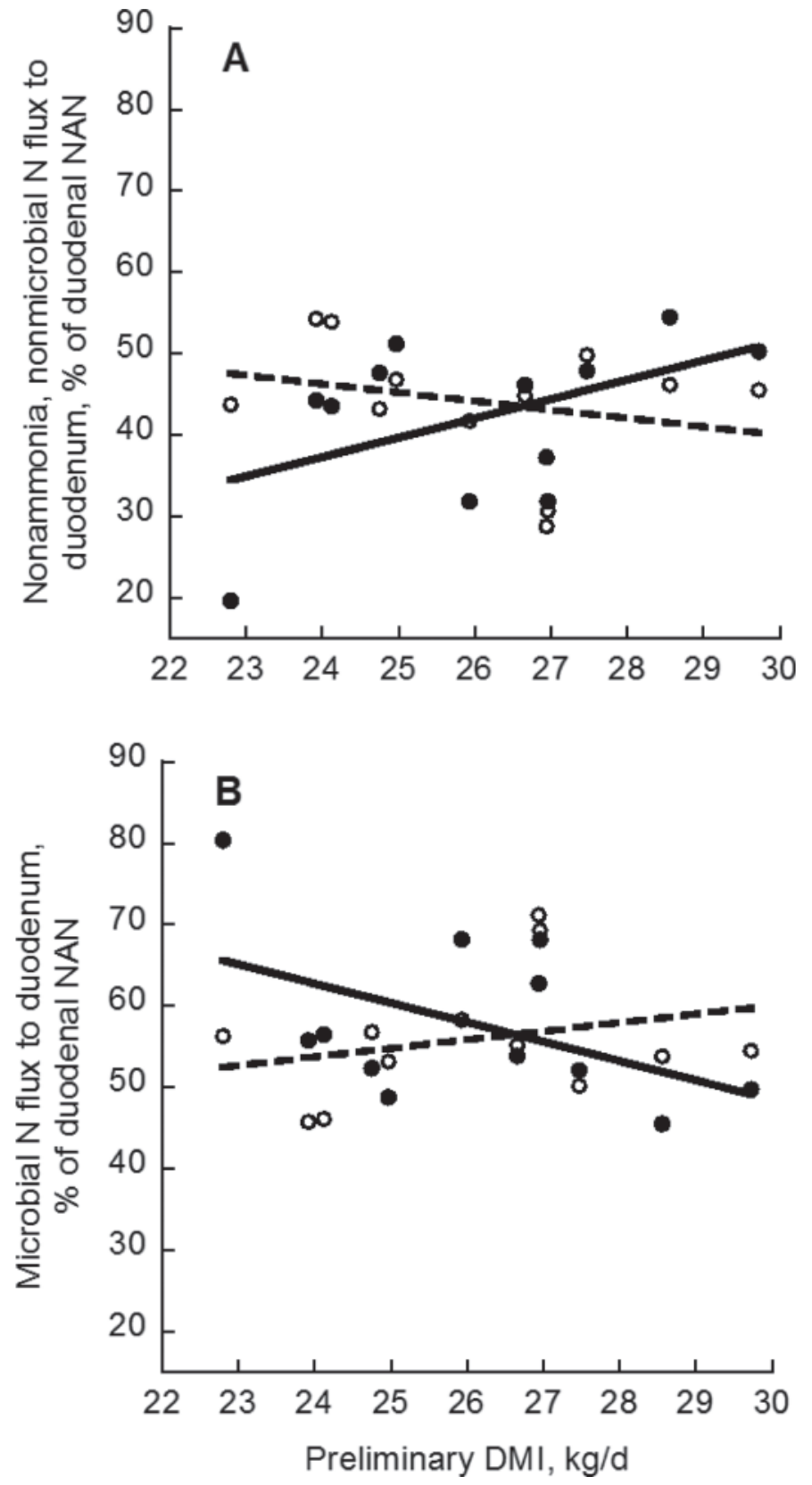

Figure 6. Interaction of long (19 mm; open circles, dashed line) and short (10 mm; closed circles, solid line) alfalfa particle length with preliminary DMI for $(\mathrm{A})$ nonammonia, nonmicrobial $\mathrm{N}$ (interaction: $P$ $=0.008$ linear; long: $P=0.39, \mathrm{R}^{2}=0.07$; short: $\left.P=0.12, \mathrm{R}^{2}=0.23\right)$ and (B) microbial $\mathrm{N}$ (interaction: $P=0.008$ linear; long: $P=0.39, \mathrm{R}^{2}$ $=0.07$; short: $\left.P=0.12, \mathrm{R}^{2}=0.23\right)$ fluxes from the rumen to duodenum expressed as percent of duodenal NAN. The preliminary DMI on the $\mathrm{x}$-axis are the mean DMI of individual cows during the final $4 \mathrm{~d}$ of the preliminary period when all cows were fed a common diet. The best-fit lines are drawn to demonstrate the significant interaction even if the individual relationships are not significant.
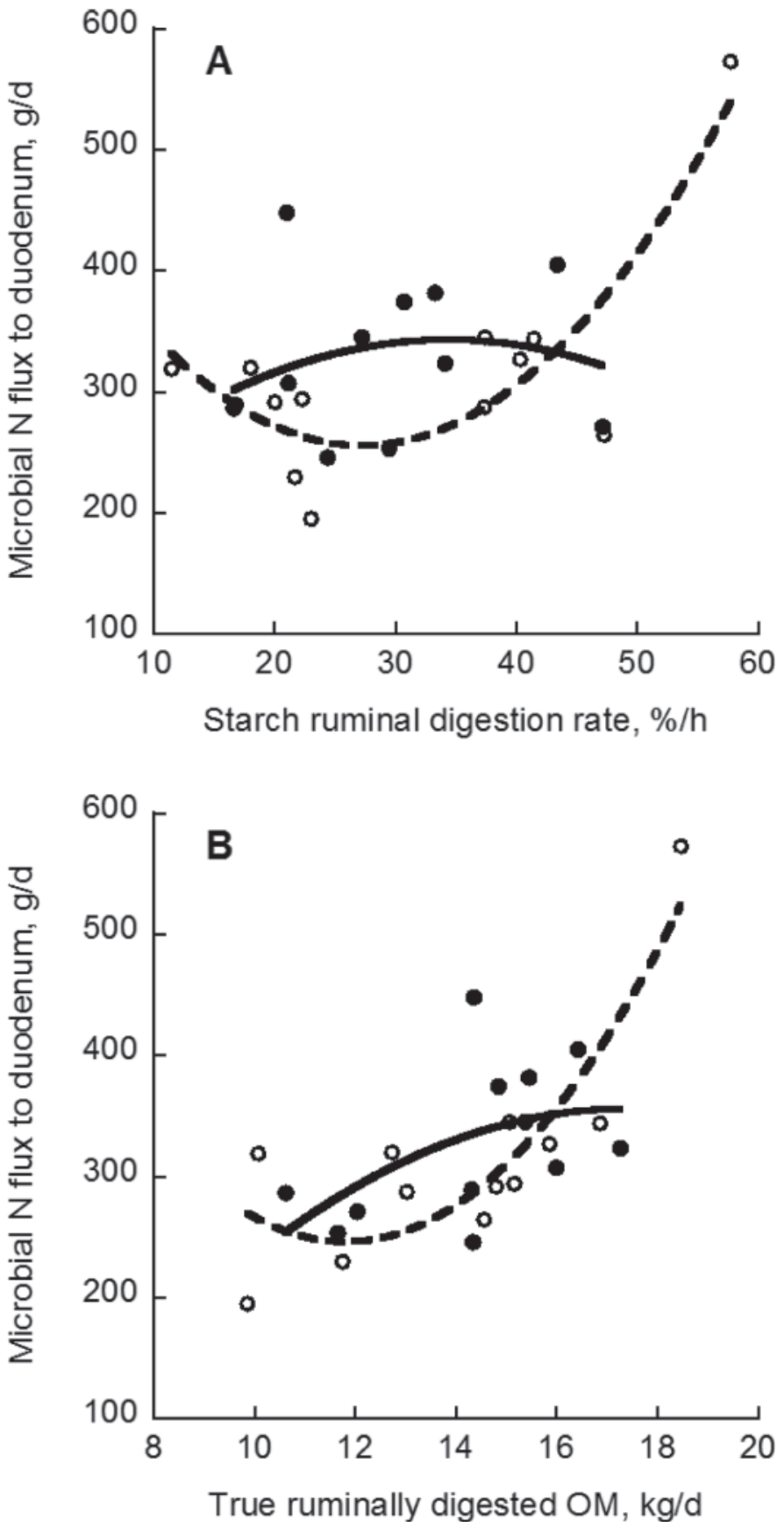

Figure 7. (A) Relationship between starch ruminal digestion rate $\left(\mathrm{k}_{\mathrm{d}}\right)$ and microbial $\mathrm{N}(\mathrm{MN})$ flux from rumen to duodenum for long (open circles, dashed line; MN flux, g/d $=\{205+(1.76 \times$ starch ruminal $\left.\left.\mathrm{k}_{\mathrm{d}}, \% / \mathrm{h}\right)+\left[0.306 \times\left(\text { starch ruminal } \mathrm{k}_{\mathrm{d}}, \% / \mathrm{h}-30.1\right)^{2}\right]\right\} ; P=$ $0.004, \mathrm{R}^{2}=0.71$ ) and short (closed circles, solid line; $P=0.78, \mathrm{R}^{2}=$ 0.05) alfalfa particle length. (B) Relationship between true ruminally digested OM (TRDOM) and MN flux from rumen to duodenum for long (MN flux, g/d $=\{-145+(30.0 \times$ TRDOM, $\mathrm{kg} / \mathrm{d})+[6.27 \times$ (TRDOM, kg/d -14.2$\left.\left.\left.)^{2}\right]\right\} ; P=0.002, \mathrm{R}^{2}=0.75\right)$ and short $(P=0.25$, $\left.\mathrm{R}^{2}=0.26\right)$ alfalfa particle length. 


\section{REFERENCES}

Allen, M. S. 1996. Physical constraints on voluntary intake of forages by ruminants. J. Anim. Sci. 74:3063-3075.

Allen, M. S. 1997. Relationship between fermentation acid production in the rumen and the requirement for physically effective fiber. J. Dairy Sci. 80:1447-1462.

Allen, M. S. 2000. Effects of diet on short-term regulation of feed intake by lactating dairy cows. J. Dairy Sci. 83:1598-1624.

AOAC. 2000. Official Methods of Analysis. 17th ed. Association of Official Analytical Chemists, Arlington, VA.

Beauchemin, K. A., L. M. Rode, and M. V. Eliason. 1997. Chewing activities and milk production of dairy cows fed alfalfa as hay, silage, or dried cubes or silage. J. Dairy Sci. 80:324-333.

Broderick, G. A., and J. H. Kang. 1980. Automated simultaneous determination of ammonia and total amino acids in rumen fluid and in vitro media. J. Dairy Sci. 63:64-75.

Cochran, R. C., D. C. Adams, J. D. Wallace, and M. L. Galyean. 1986. Predicting digestibility of different diets with internal markers: Evaluation of four potential markers. J. Anim. Sci. 63:1476-1483.

Cochran, R. C., E. S. Vanzant, and T. DelCurto. 1988. Evaluation of internal markers isolated by alkaline hydrogen peroxide incubation and acid detergent lignin extraction. J. Anim. Sci. 66:3245-3251.

Cook, R. D., and S. Weisberg. 1982. Residuals and Influence in Regression. Chapman and Hall, New York, NY.

Dixon, R. M., and L. P. Milligan. 1985. Removal of digesta components from the rumen of steers determined by sieving techniques and fluid, particulate and microbial markers. Br. J. Nutr. 53:347-362.

Einarson, M. S., J. C. Plaizier, and K. M. Wittenberg. 2004. Effects of barley silage chop length on productivity and rumen conditions of lactating dairy cows fed total mixed ration. J. Dairy Sci. 87:2987-2996.

Goering, H. K., and P. J. Van Soest. 1970. Forage Fiber Analysis (Apparatus, Reagents, Procedures, and Some Applications). Agric. Handbook No. 379. Agricultural Research Service, United States Department of Agriculture, Washington, DC.

Grant, R. J. 1997. Interactions among forages and nonforage fiber sources. J. Dairy Sci. 80:1438-1446.

Hach, C. C., B. K. Bowden, A. B. Lopelove, and S. V. Brayton. 1987. More powerful peroxide Kjeldahl digestion method. J. AOAC 70:783-787.

Huhtanen, P., and S. Jaakkola. 1993. The effects of forage preservation method and proportion of concentrate on digestion of cell wall carbohydrates and rumen digesta pool size in cattle. Grass Forage Sci. 48:155-165.

Joy, M. T., E. J. DePeters, J. G. Fadel, and R. A. Zinn. 1997. Effects of corn processing on the site and extent of digestion in lactating cows. J. Dairy Sci. 80:2087-2097.

Kammes, K. L., and M. S. Allen. 2012. Nutrient demand interacts with grass particle length to affect digestion responses and chewing activity in dairy cows. J. Dairy Sci. 95:807-823.

Karkalas, J. 1985. An improved enzymatic method for the determination of native and modified starch. J. Sci. Food Agric. 36:10191027.

Kononoff, P. J., and A. J. Heinrichs. 2003. The effect of reducing alfalfa haylage particle size on cows in early lactation. J. Dairy Sci. 86:1445-1457.

Krause, K. M., and D. K. Combs. 2003. Effects of forage particle size, forage source, and grain fermentability on performance and ruminal pH in midlactation cows. J. Dairy Sci. 86:1382-1397.

Lammers, B. P., D. R. Buckmaster, and A. J. Heinrichs. 1996. A simplified method for the analysis of particle sizes of forage and total mixed rations. J. Dairy Sci. 79:922-928.
Mertens, D. R. 2002. Gravimetric determination of amylase-treated neutral detergent fiber in feeds using refluxing in beakers or crucibles: Collaborative study. J. AOAC Int. 85:1217-1240.

Mooney, C. S., and M. S. Allen. 1997. Physical effectiveness of the neutral detergent fiber of whole linted cottonseed relative to that of alfalfa silage at two lengths of cut. J. Dairy Sci. 80:2052-2061.

NRC. 2001. Nutrient Requirements of Dairy Cattle. 7th rev. ed. Natl. Acad. Sci., Washington, DC.

Nørgaard, P. 1993. Saliva secretion and acid-base status of ruminants: A review. Acta Vet. Scand. Suppl. 89:93-100.

Oba, M., and M. S. Allen. 1999. Effects of brown midrib 3 mutation in corn silage on dry matter intake and productivity of high-yielding dairy cows. J. Dairy Sci. 82:135-142.

Oba, M., and M. S. Allen. 2003. Effects of corn grain conservation method on feeding behavior and productivity of lactating dairy cows at two dietary starch concentrations. J. Dairy Sci. 86:174183.

Onetti, S. G., R. D. Shaver, S. J. Bertics, and R. R. Grummer. 2003. Influence of corn silage particle length on the performance of lactating dairy cows fed supplemental tallow. J. Dairy Sci. 86:29492957.

Poore, M. H., J. A. Moore, T. P. Eck, R. S. Swingle, and C. B. Theurer. 1993. Effect of fiber source and ruminal starch degradability on site and extent of digestion in dairy cows. J. Dairy Sci. $76: 2244-2253$

Randby, Å. T., T. Garmo, M. Eknæs, and E. Prestløkken. 2008. Effect of grass silage chop length on intake and milk production by dairy cows. Grassl. Sci. Eur. 13:768-770.

Robinson, P. J., S. Tamminga, and A. M. van Vuuren. 1987. Influence of declining level of feed intake and varying proportion of starch in the concentrate on rumen ingesta quantity, composition and kinetics of ingesta turnover in dairy cows. Livest. Prod. Sci. 17:37-62.

Soita, H. W., D. A. Christensen, and J. J. McKinnon. 2000. Influence of particle size on the effectiveness of the fibre in barley silage. J. Dairy Sci. 83:2295-2300.

Stensig, T., and P. H. Robinson. 1997. Digestion and passage kinetics of forage fiber in dairy cows as affected by fiber-free concentrate in the diet. J. Dairy Sci. 80:1339-1352.

Tafaj, M., Q. Zebeli, Ch. Baes, H. Steingass, and W. Drochner. 2007. A meta-analysis examining effects of particle size of total mixed rations on intake, rumen digestion and milk production in highyielding dairy cows in early lactation. Anim. Feed Sci. Technol. 138:137-161.

Voelker, J. A., G. M. Burato, and M. S. Allen. 2002. Effect of pretrial milk yield on responses of feed intake, digestion, and production to dietary forage concentration. J. Dairy Sci. 85:2650-2661.

Voelker Linton, J. A., and M. S. Allen. 2008. Nutrient demand interacts with forage family to affect intake and digestion responses in dairy cows. J. Dairy Sci. 91:2694-2701.

Wildman, E. E., G. M. Jones, P. E. Wagner, R. L. Boman, H. F. Troutt Jr., and T. N. Lesch. 1982. A dairy cow body condition scoring system and its relationship to selected production characteristics. J. Dairy Sci. 65:495-501.

Yang, W. Z., and K. A. Beauchemin. 2004. Grain processing, forageto-concentrate ratio, and forage length effects on ruminal nitrogen degradation and flows of amino acids to the duodenum. J. Dairy Sci. 87:2578-2590.

Yang, W. Z., K. A. Beauchemin, and M. L. Rode. 2001. Effects of grain processing, forage to concentrate ratio, and forage particle size on rumen $\mathrm{pH}$ and digestion in dairy cows. J. Dairy Sci $84: 2203-2216$

Zinn, R. A., and F. N. Owens. 1986. A rapid procedure for purine measurement and its use for estimating net ruminal protein synthesis. Can. J. Anim. Sci. 66:157-166. 